\title{
Near-Fault Ground Motion Influence on the Seismic Responses of a Structure with Viscous Dampers considering SSI Effect
}

\author{
Jinping Yang $\left(\mathbb{D},{ }^{1}\right.$ Peizhen Li $\left(\mathbb{D},{ }^{2}\right.$ Hang Jing $\mathbb{D},^{1}$ and Meng Gao $\mathbb{D}^{1}$ \\ ${ }^{1}$ College of Civil Engineering, Henan University of Technology, Zhengzhou, China \\ ${ }^{2}$ State Key Laboratory of Disaster Reduction in Civil Engineering, Tongii University, Shanghai, China
}

Correspondence should be addressed to Hang Jing; hangjing@haut.edu.cn

Received 28 October 2020; Revised 23 January 2021; Accepted 28 January 2021; Published 8 February 2021

Academic Editor: Raffaele Landolfo

Copyright (c) 2021 Jinping Yang et al. This is an open access article distributed under the Creative Commons Attribution License, which permits unrestricted use, distribution, and reproduction in any medium, provided the original work is properly cited.

\begin{abstract}
This paper studies the influence of the characteristics of the near-fault ground motion on the seismic responses of the structure with energy dissipation devices including soil-structure interaction (SSI). A ten-story reinforced concrete frame rested on soft site is introduced, and the viscous dampers added in the frame are designed. The numerical analysis method of the soil-structure system with viscous dampers is established through ANSYS program. In addition, the response spectra of the main characteristics of the near-fault ground motion, like hanging wall effect, velocity pulse-like effect, and forward-directivity effect, are investigated carefully to learn the features of spectra energy distribution. And then, the dynamic time-history analysis is performed on the SSI system with and without viscous dampers subjected to the selected near-fault ground motion. The study reveals that the seismic responses of the structure subjected to near-fault ground motion with hanging wall effect are obviously larger than those of the footwall effect, indicating the distinct hanging wall effects on the structural dynamic responses. In addition, the performance of the structure with viscous dampers is more influenced by the ground motion containing fling-step effect than that with forwarddirectivity effect. Moreover, the influence of the horizontal component of forward-directivity ground motion on the seismic responses of the structure is more obvious than that of parallel component ground motion. Consequently, the hanging wall effect, velocity pulse, and horizontal component in forward-directivity effect of the near-fault ground motion have distinct influence on the seismic responses of the structure with energy dissipation devices considering SSI effect, providing insight towards the performance-based seismic design of buildings rested at the near-fault sites considering the seismic SSI effect.
\end{abstract}

\section{Introduction}

The motion characteristics of the ground motion in the nearfault region are obviously different from ordinary far-field ones. The main characteristics of far-field ground motion are low peak ground acceleration (PGA) and high frequency, while high peak ground velocity (PGV) and long-period pulse are distinct features in the near-fault seismic motion [1]. Moreover, in many earthquakes in the past, e.g., the 1994 Northridge earthquake, the 1995 Kobe earthquake, and the 1999 Chi-Chi earthquake, it has been observed that the seismic focus of these earthquakes is very close to the city, and the earthquakes caused serious deaths and economic losses. Consequently, the influence of near-fault ground motion on the structural responses, which is an important research direction in civil engineering, has been widely studied in recent years.

The near-fault ground motions are mainly related to the focal mechanism, the relationship between fault rupture direction and site, and the relative sliding direction of the fault surface. In addition, the pulse-like ground motion caused by the directional effect and the fling-step effect is the prominent feature of near-fault ground motion. Moreover, the ground motion containing velocity pulses is the most common kind of these pulsed motions. It has a pulse-like waveform, a longer pulse period, and abundant medium and long-period components [2]. The ratio of PGV to PGA is large, which may result in large-scale permanent ground displacement. In addition, the hanging wall effect and vertical seismic motion effect [3] are the other characteristics 
of near-fault ground motion. To identify the ground motions including strong velocity pulses and the forward-directivity effects, many methods are established, such as wavelet analysis [4], empirically calibrated framework [5], stochastic modeling [6], a new method based on the Hilbert-Huang Transform (HHT) [2], and the variational mode decomposition technique [7].

After grasping the characteristics of the near-fault ground motions, more and more studies and interests are focused on the influence of the near-fault ground motions on the structure in civil engineering, such as the comparisons drift demands of steel frames under far-field shakings and near-fault mainshock-aftershock seismic shakings [8], the influence of pulse parameters on the seismic response of long-period bridges [9], the effects of Wenchuan earthquake on structural seismic resilience [10], the impacts of velocity pulses on the inelastic displacement ratio of single-degree-of-freedom systems [11], and the effects of near-fault ground motions with large, medium, and small pulse periods on a core-wall tall building [12]. These research studies reveal that the seismic response of the bridge and structure and the collapse and demolition risks of frames are increased by the pulse-like near-fault ground motions [13].

The dynamic response of practical engineering structure is much more complex than the fixed-base condition since an engineering structure is influenced by the seismic soil-structure-interaction (SSI) effect [14]. Intensive research studies are devoted to the nonlinear dynamic SSI effect in the past few decades [15]. Combining the SSI effect with near-fault ground motions is becoming a hot issue in recent years. These studies present the influence of near-fault ground motions on the seismic performance of many kinds of engineering structures with SSI effect, such as nonlinear MDOF structures [16], cablestayed bridge [17], roof-type steel structures [18], high concrete face rockfill dam [19], rocking soil-structure systems considering foundation uplifting and soil plasticity [20], and complex historical stone masonry mosque [21]. Other topics highlight the seismic demands of asymmetric buildings with SSI [22], seismic demand analysis of a typical midrise slender shear wall [23], inertial SSI effects on linear and bilinear structures [24], rocking of rigid structures uplifting from their support under strong earthquakes [25], effects of inertial SSI on damping coefficients [26], higher-mode effects for multistory structures [27], and a practical displacement-based framework for seismic design of flexible-base structures [28]. These findings conclude that the seismic response of the structure increases with the earthquake ground motions due to SSI [29], because the structural response parameters are noticeably influenced by the near-fault ground motions [30,31], and due to the type of fault mechanism [32]. Ignoring the SSI effect and near-fault ground motions may give rise to inaccurate estimation of the responses of bridge frames and structures [20,33].

In recent decades, many technologies of shock absorption and shock partition have been developed in recent years [34-37]. Moreover, energy dissipation device is relative widely applied to engineering structures due to its simple concept, clear mechanism, obvious mitigation performance, and reliable operation [38]. However, its effectiveness in controlling structural responses and the seismic characteristics of the structure under near-fault ground motions is still under discussion [39]. Some results conclude that the energy dissipation performance is overestimated [40] and the structure may still experience plastic deformation under near-fault ground motions [41].

Although some studies have been carried out on the characteristics of near-fault ground motions and their influence on the structural responses [42], there are few concerns about the dynamic responses of the structure in the SSI system with energy dissipation dampers subjected to near-fault ground motions. Therefore, in this work, the seismic response of structures subjected to a set of near-fault earthquakes with different characteristics is investigated to evaluate the influential mechanism of the near-fault ground motions on the energy dissipation structure in the SSI system.

This study introduces the nonlinear numerical methods of the SSI system with viscous dampers located on a soft site in Section 2. The response spectra $f$ of the selected near-fault ground motions and the dynamic responses of the structure, i.e., the acceleration, displacement, interstory drift, and interstory shear force, subjected to the near-fault ground shakings with hanging wall effect, the velocity pulse-like effect, and forward-directivity effect are presented fully in Section 3, 4, and 5, respectively.

\section{Analytical Modeling of the SSI System with Energy Dissipation Dampers}

2.1. Introduction to Practical Engineering. The practical engineering is a ten-story reinforced concrete frame structure supported by a piled raft foundation on the oft site. The floor plane of the standard story is shown in Figure 1. The sectional dimensions of the column, beam, and pile are $550 \mathrm{~mm} \times 550 \mathrm{~mm}, 300 \mathrm{~mm} \times 500 \mathrm{~mm}$, and $450 \mathrm{~mm} \times 450$ $\mathrm{mm}$, respectively. The dead load of the standard floor is $5.0 \mathrm{kN} / \mathrm{m}^{2}$, and the live load is $2.0 \mathrm{kN} / \mathrm{m}^{2}$. C35 concrete, whose axial compression resistance strength is $23.4 \mathrm{~N} / \mathrm{mm}^{2}$, is applied to the superstructure and foundation. The type of site belongs to IV class, and the intensity of earthquake is 8 according to the Chinese seismic code. The pile length is $38 \mathrm{~m}$, and the soil depth is $120 \mathrm{~m}$. Table 1 lists the physical and mechanical properties of the soil in the practical engineering.

2.2. Parameters of Viscous Dampers. The first period and damping ratio of the structure excluding SSI and considering SSI are $1.456 \mathrm{~s}$ and $1.841 \mathrm{~s}$ and $5 \%$ and $6.1 \%$, respectively $[43,44]$. The maximum interstory drift is $1 / 412$, larger than the limit $1 / 550$. In this practical engineering, every floor is equipped with four nonlinear viscous dampers on the side span, as shown in Figure 2. The design parameters of dampers and structure are shown in Table 2 based on the design method of viscous dampers [44-46]. 


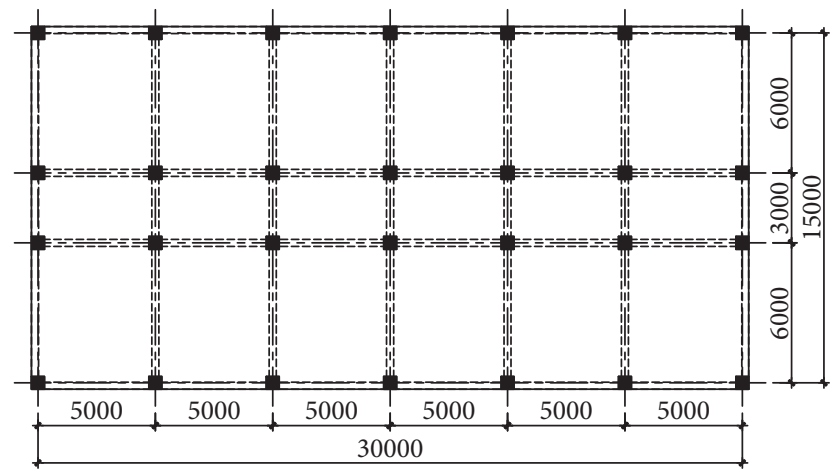

Figure 1: Standard floor plane of the frame structure (unit: $\mathrm{m}$ ).

Table 1: Physical and mechanical properties of the soil.

\begin{tabular}{|c|c|c|c|c|c|c|c|}
\hline Layer & Soil & $\begin{array}{l}\text { Base depth } \\
(\mathrm{m})\end{array}$ & $\begin{array}{c}\text { Density } \rho(\mathrm{t} / \\
\left.\mathrm{m}^{3}\right)\end{array}$ & $\begin{array}{l}\text { Poisson's } \\
\text { ratio }\end{array}$ & $\begin{array}{c}\text { Wave velocity } \\
v_{\mathrm{s}}(\mathrm{m} / \mathrm{s})\end{array}$ & $\begin{array}{c}\text { Dynamic shear } \\
\text { modulus } G_{\mathrm{d}}(\mathrm{MPa})\end{array}$ & $\begin{array}{l}\text { Dynamic elastic } \\
\text { modulus } E_{\mathrm{d}}(\mathrm{MPa})\end{array}$ \\
\hline (1) & Plain fill & 2.2 & - & - & 107 & - & - \\
\hline (2) & Silty clay & 3.8 & 1.86 & 0.3 & 125 & 29.1 & 75.6 \\
\hline (3) & Muddy silty clay & 10.3 & 1.76 & 0.35 & 111 & 21.7 & 58.5 \\
\hline (4) & Mucky clay & 19.4 & 1.68 & 0.42 & 161 & 43.5 & 123.7 \\
\hline (5) & Clay & 25.9 & 1.74 & 0.42 & 214 & 79.7 & 226.3 \\
\hline (6) & Silty clay & 29 & 1.96 & 0.25 & 226 & 100.1 & 250.3 \\
\hline (7) $1 \mathrm{a}$ & Sandy silt & 36.3 & 1.88 & 0.3 & 193 & 70.0 & 182.1 \\
\hline (7) $1 b$ & Silt & 58.9 & 1.89 & 0.3 & 274 & 141.9 & 368.9 \\
\hline (8) 1 & Silty clay & 61.2 & 1.94 & 0.3 & 268 & 139.3 & 362.3 \\
\hline (8) 2 & $\begin{array}{c}\text { Silty clays and clayey silts } \\
\text { interbedding }\end{array}$ & 66.7 & 1.9 & 0.3 & 322 & 197.0 & 512.2 \\
\hline (9) & Silt & $>66.7$ & 1.9 & 0.3 & 298 & 168.7 & 438.7 \\
\hline
\end{tabular}

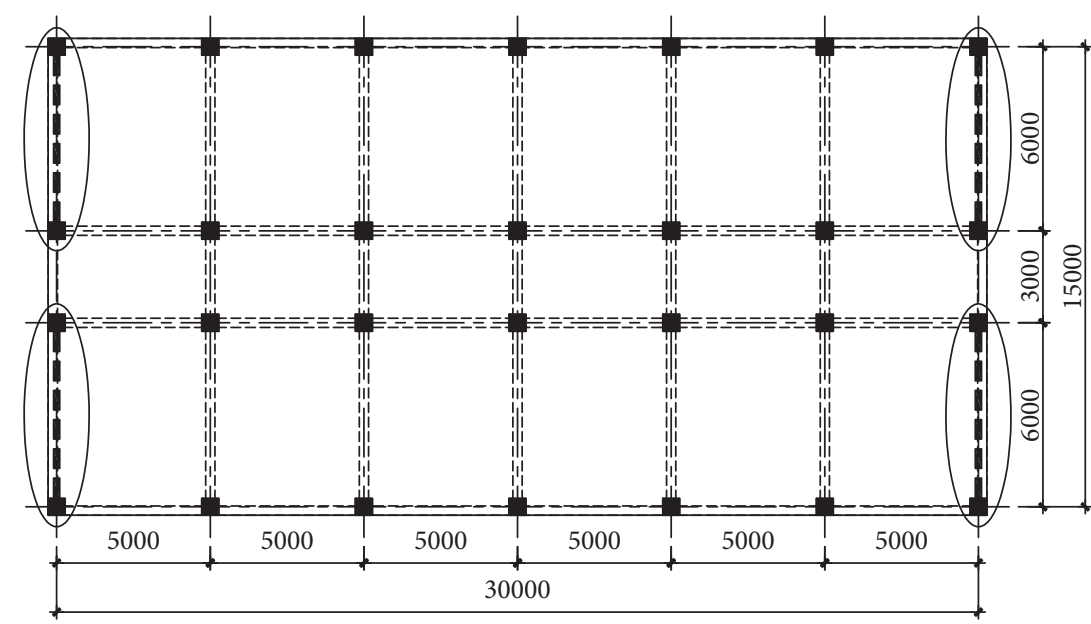

(a)

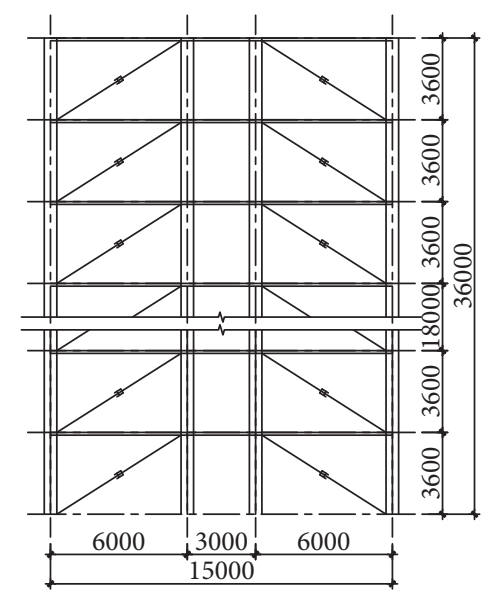

(b)

Figure 2: Arrangement of viscous dampers in: (a) plane and (b) elevation (unit: m).

2.3. Simulation Method. In this present study, a proper threedimensional nonlinear analytical method is established based on ANSYS software to evaluate the dynamic time-history analyses of the pile-soil-structure with viscous dampers rested on soft site subjected to near-fault ground motions. In the numerical model, the column and beams in the superstructure and the piles adopt nonlinear beam element beam 4 type.
Three-dimensional solid element solid45 type is used to model the soil and foundation. In addition, the floor of the structure is modeled as three-dimensional shell element shell63 type. Furthermore, an equivalent linear model is developed and incorporated into the ANSYS program based on the parameter design language of ANSYS to realize the nonlinear dynamic behavior of soils [47]. The viscous 
TABLe 2: Design information of viscous dampers.

\begin{tabular}{|c|c|c|c|c|c|c|c|}
\hline Story & $\begin{array}{c}\text { Floor } \\
\text { mass }(\mathrm{t})\end{array}$ & $\begin{array}{c}\text { Peak displacement } \\
(\mathrm{mm})\end{array}$ & $\begin{array}{l}\text { Interstory } \\
\text { drift }\end{array}$ & $\begin{array}{c}\text { Damping } \\
\text { force }(\mathrm{kN})\end{array}$ & $\begin{array}{l}\text { Damping force of } \\
\text { each damper }(\mathrm{kN})\end{array}$ & $\begin{array}{l}\text { Damping coefficient } \\
\left(\mathrm{kN} \cdot(\mathrm{s} / \mathrm{m})^{0.2}\right)\end{array}$ & $\begin{array}{l}\text { Damping coefficient } \\
(\mathrm{kN} \cdot(\mathrm{s} / \mathrm{m}))\end{array}$ \\
\hline 1 & 430.6 & 5.34 & $1 / 0674$ & 1451.85 & 500 & 640 & 1600 \\
\hline 2 & 430.6 & 13.81 & $1 / 0425$ & 1306.67 & 500 & 640 & 1600 \\
\hline 3 & 430.6 & 22.54 & $1 / 0412$ & 1161.48 & 400 & 500 & 1300 \\
\hline 4 & 430.6 & 30.91 & $1 / 0428$ & 1016.30 & 400 & 500 & 1300 \\
\hline 5 & 430.6 & 38.64 & $1 / 0460$ & 871.112 & 300 & 380 & 1000 \\
\hline 6 & 430.6 & 45.59 & $1 / 0508$ & 725.927 & 300 & 380 & 1000 \\
\hline 7 & 430.6 & 51.57 & $1 / 0584$ & 580.741 & 200 & 250 & 650 \\
\hline 8 & 430.6 & 56.45 & $1 / 0708$ & 435.556 & 200 & 250 & 650 \\
\hline 9 & 430.6 & 60.10 & $1 / 935$ & 290.371 & 100 & 130 & 300 \\
\hline 10 & 430.6 & 62.48 & $1 / 1430$ & 145.185 & 100 & 130 & 300 \\
\hline
\end{tabular}

dampers are simulated by control element combin 37 type and verified properly by an analytical modeling of a large-scale shaking table test [38].

In SSI systems, the damping models of each material, such as soil and concrete frame superstructure, are loaded to the simulation process separately. The generally known Rayleigh damping as shown in the following equations is applied to the SSI system:

$$
\begin{aligned}
& C=\alpha M+\beta K, \\
& \xi_{i}=\frac{\alpha}{2 \omega_{i}}+\frac{\beta \omega_{i}}{2},
\end{aligned}
$$

where $M$ and $K$ are the mass matrix and stiffness matrix, respectively, and $\xi_{i}$ and $\omega_{i}$ are the damping ratio and natural frequency (circular frequency) of the $i$-order mode shape, respectively. The soil damping ratio is iteratively determined from the physical and mechanical properties of the soil shown in Table 1. The damping ratio of the superstructure can be consulted to the modal identification results.

Soil dynamic constitutive models are based on the skeleton curves of the Davidenkov model [47].

Viscoelastic boundary is applied to the limited lateral sides of soil. The coefficients of stiffness and damping in normal and tangential directions are expressed as follows:

$$
\begin{gathered}
K_{N}=\alpha_{N} \frac{G}{R}, \\
C_{N}=\rho v_{p} . \\
K_{T}=\alpha_{T} \frac{G}{R}, \\
C_{T}=\rho v_{s},
\end{gathered}
$$

where $K_{N}$ and $K_{T}$ are the stiffness coefficients in normal and tangential directions, respectively, $C_{N}$ and $C_{T}$ are the damping coefficients in normal and tangential directions, respectively, $R$ is the distance from the wave source to the artificial boundary, $v_{p}$ and $v_{s}$ are the velocities of $P$ wave and $S$ wave, respectively, and $\alpha_{N}$ and $\alpha_{T}$ are correction factors of viscoelastic boundary in normal and tangential directions and recommended to be $4 / 3$ and $2 / 3$, respectively, in the three-dimensional simulation.
2.4. Soil Boundary. In the SSI system, the computed regions of the soil and the artificial boundary are important to the property of a practical model [48]. Three models with different soil boundaries are built in this present study. The soil boundaries are 40 times of the lateral dimension of the structure with free boundary, 20 times of the lateral dimension of the structure with viscoelastic boundary, and 20 times of the lateral dimension of the structure with free boundary, respectively. It is considered that the free boundary model with 40 times of the structural lateral dimension can simulate the infinite soil in the half space approximately. Figure 3 shows the meshed SSI model, whose soil boundary is 20 times of the structural lateral dimension. The dynamic results demonstrated that the viscoelastic soil boundary with 20 times of the structural lateral dimension can simulate the infinite soil boundary well.

\section{Influence of Hanging Wall Effect on the SSI System with Viscous Dampers}

The site above the hanging wall located in the dip slip fault is much closer to the fault by comparing with the site in the footwall with the same fault distance. Therefore, the ground motion with a short period containing the hanging wall is much stronger than that with the footwall, which is so-called the hanging wall effect. It is a distinct characteristic of the near-fault ground motion and mainly caused by the asymmetric distribution of the inclined faults.

\subsection{Hanging Wall and Footwall Effect of Ground Motions.} Different recorded accelerations of the hanging wall and the footwall are selected in the section, as shown in Table 3. The selected accelerations are all Chi-Chi earthquakes to eliminate the influence of different focal mechanisms [49].

Figure 4 shows two acceleration time-histories and their corresponding Fourier spectra $f$ of the hanging wall and footwall due to the space limitation. It can be obtained from the figure that the energy of the hanging wall ground motions and footwall ground motions is mainly in low-frequency ranges. Moreover, the energy range of the ground motion containing the hanging wall effect is much wider than that footwall effect.

To maintain the true and unique characteristics of the near-fault ground motion and examine its influence on the 


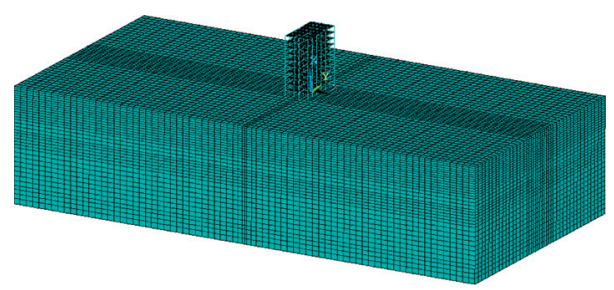

Figure 3: The meshed SSI model with soil boundary 20 times of the structural lateral dimension.

TABLE 3: The selected accelerations of the hanging wall and footwall.

\begin{tabular}{|c|c|c|c|c|c|c|c|c|}
\hline Characteristics of gr & d motion & & & & Station & & & \\
\hline & Hanging wall & TCU052 & TCU071 & TCU072 & TCU074 & TCU078 & TCU079 & TCU084 \\
\hline Hanging wall effect & Footwall & CHY025 & CHY101 & TCU067 & TCU075 & TCU102 & TCU110 & TCU117 \\
\hline
\end{tabular}

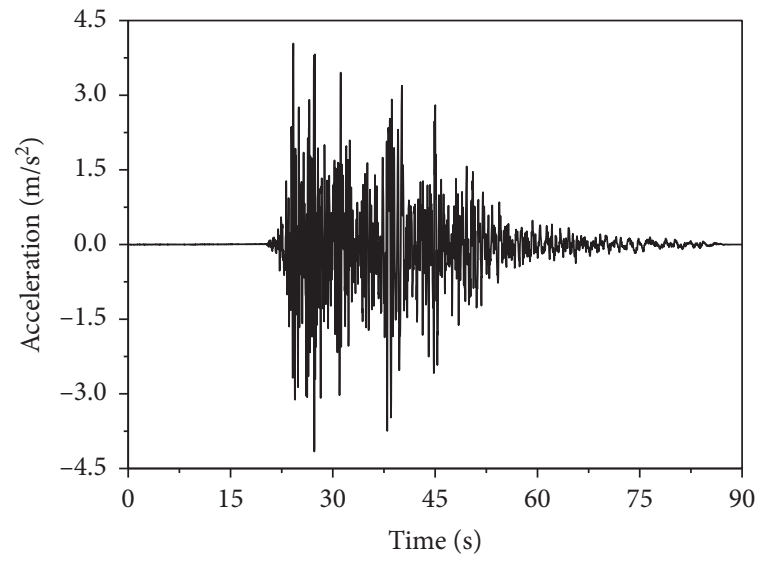

- TCU078

(a)

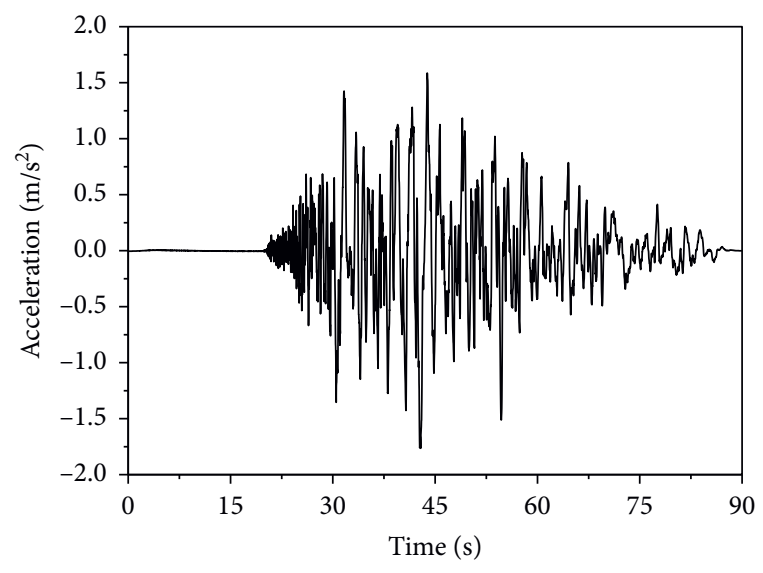

TCU110

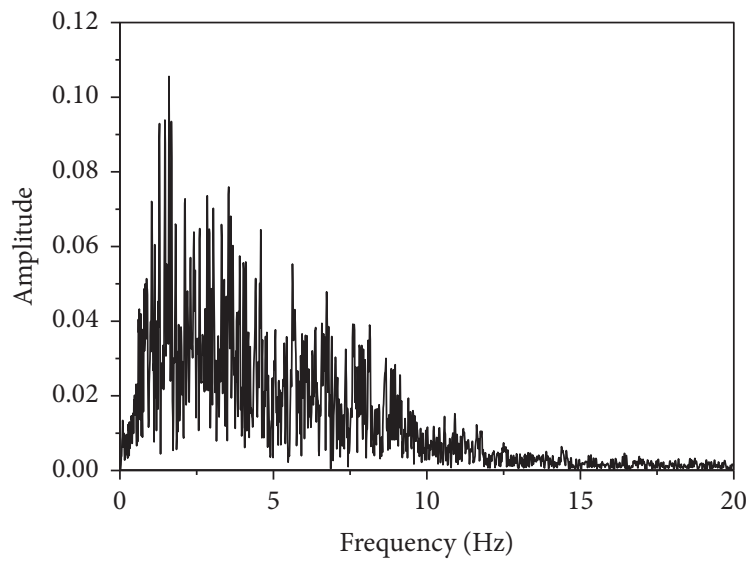

TCU078

(b)

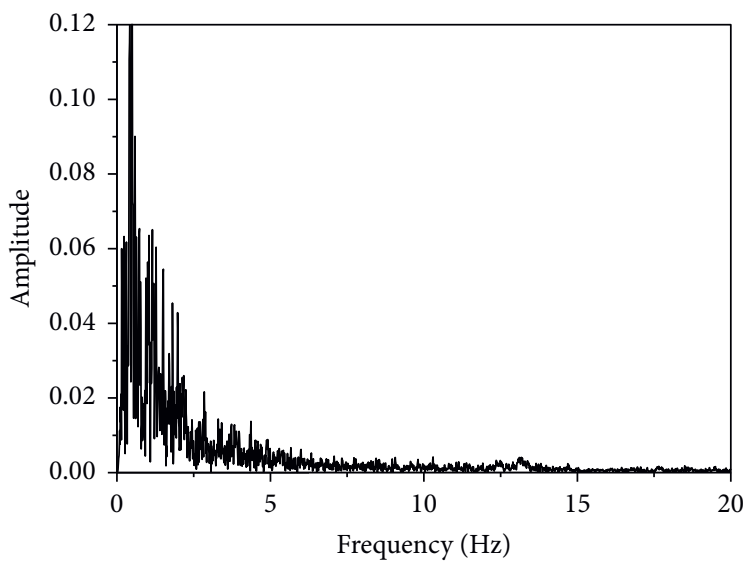

TCU110

(c)

(d)

FIgURE 4: (a) The acceleration time-history of the wave from TCU078 station; (b) the corresponding Fourier spectra of the wave from TCU078 station; (c) the acceleration time-history of the wave from TCU110 station; (d) the corresponding Fourier spectra of the wave from TCU110 station.

SSI system with energy dissipations, there is no adjustment to the recorded ground motions generally. However, considering the modulation of PGA in the present code for seismic design of buildings in China, the acceleration response spectra and structural dynamic responses of the SSI system with energy dissipations after the modulation of PGA 
are also studied. Figure 5 shows the average response spectra of the selected recoded hanging wall and footwall ground motions with and without amplitude modulation. The PGA of the ground motion is adjusted to $70 \mathrm{~cm} / \mathrm{s}^{2}$ based on the seismic code in the $8^{\circ}$ seismic intensity region. It can be seen from the figure that the hanging wall effect is obvious in short periods whether the PGA of the recorded ground motions is amplified or not, indicating the significant effect of high-frequency components in near-fault records on the responses of the structure [13]. Moreover, the hanging wall effect is decreased and not distinct after amplitude modulation.

3.2. Acceleration of the Superstructure. The dynamic timehistory analysis is performed on the SSI system with and without viscous dampers subjected to the selected ground motions with a hanging wall and footwall. Figure 6 shows the average peak accelerations of the superstructure with and without amplitude modulation. It can be obtained that the nonlinear viscous dampers exert a good performance on decreasing the acceleration responses of the superstructure. In addition, the acceleration responses under the original PGA case are obviously larger than those under the amplified PGA case. More interestingly, the peak acceleration of the hanging wall in the original PGA case is larger than that of footwall, indicating the distinct hanging wall effect in the original records, while the conclusions are altered in the amplified PGA case. Therefore, the hanging wall effect is obvious in the initial state of the ground motions, while the amplitude modulation may decrease the hanging wall effect in the acceleration responses of the structure [49].

3.3. Displacement of the Superstructure. The average peak displacements of the superstructure with and without amplitude modulation are shown in Figure 7, which reveals the effective influence of the nonlinear viscous dampers on decreasing the displacement responses of the superstructure. Similar to the acceleration responses, the displacement responses subjected to the original records are clearly larger than those under the amplified PGA case. In addition, the displacement is larger in the hanging wall than that in the footwall without amplitude modulation, while the hanging wall effect is not obvious after the amplified modulation of the ground motions.

3.4. Interstory Drift of the Superstructure. In the performance-based structural design, interstory drift is an important indicator due to its application to investigate the damage performance state of the structure under the ground motions. Figure 8 shows the average interstory drift of the structure along the floor under the seismic excitations of the selected accelerations in the hanging wall and footwall. It reveals that the viscous dampers have a good role in decreasing the interstory drift responses of the structure. Moreover, the interstory drift is larger in the case of without amplified modulation of the ground motions than the amplitude modulation, whereas the responses in the hanging wall case are smaller than those in the foot wall with the modulation of PGA. This evaluates that the hanging wall effect may be underestimated with the modulation of PGA in near-fault ground motions.

3.5. Interstory Shear Force of the Superstructure. Figure 9 presents the average interstory shear force of the structure along the floor under the seismic excitations in the hanging wall and footwall without and with amplitude modulation. The interstory shear force on the bottom floors is generally the largest. Moreover, the superstructure subjected to the original excitations in the hanging wall experiences more interstory shear force than that in the footwall cases, demonstrating the distinct hanging wall effect in the nearfault ground motions, while the conclusion is contrary with the modulation of PGA. This is similar to the acceleration findings described in Section 3.1.

It can be illustrated from the above dynamic responses of the structure that the accelerations, displacement, interstory drift, and interstory shear force are obviously larger under the hanging wall seismic excitations than those under the footwall excitations, indicating the distinct hanging wall effect on the structural dynamic responses. However, the hanging wall effect is altered and not obvious with the modulation of PGA. Then, it did not suggest the real features of the structural response subjected to original near-fault ground motions.

\section{Influence of Velocity Pulse on SSI System with Viscous Dampers}

High-energy velocity pulse is another significant feature of the near-fault ground motion. Its main characteristics are long period, pulse-like waveforms, and distinct high peak values, which have significant damage to structures in the SSI system [2]. Therefore, more attention should be paid to the velocity pulses in the near-fault ground motion. There are two types of the velocity pulse. One is the pulse excited by the forward-directivity effect. It is a two-way velocity pulse, which occurs mainly in the direction perpendicular to the fault. The other kind is the pulse excited by the fling-step effect. It is a unidirectional velocity pulse, which mainly occurs in the direction parallel to the fault. The influences of the two kinds of velocity pulses on the seismic responses of the SSI system with energy dissipation devices are presented in this section.

4.1. Velocity Pulse-Lie Ground Motions. The selected three kinds of earthquakes, forward-directivity velocity pulse, fling-step velocity pulse, and nonspeed velocity pulse are all from Chi-Chi earthquakes to eliminate the influence of different focal mechanisms. Table 4 lists the station information of the selected velocity pulses. The PGV and PGA of the three kinds of velocity pulse records are larger than $30 \mathrm{~cm} / \mathrm{s}$ and $100 \mathrm{~cm} / \mathrm{s}^{2}$, respectively. The fault distance is within $20 \mathrm{~km}$.

Three acceleration time-histories and their corresponding Fourier spectra of the three kinds of ground 


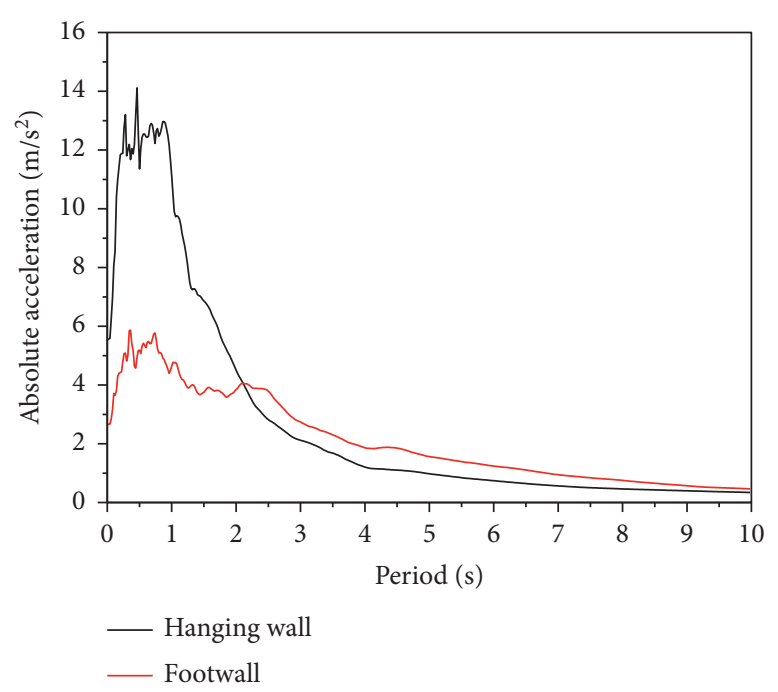

(a)

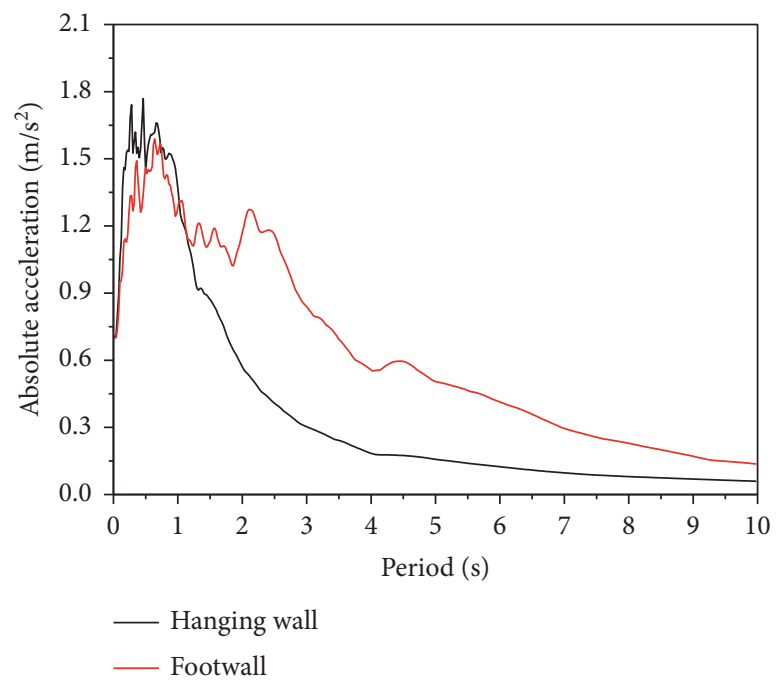

(c)

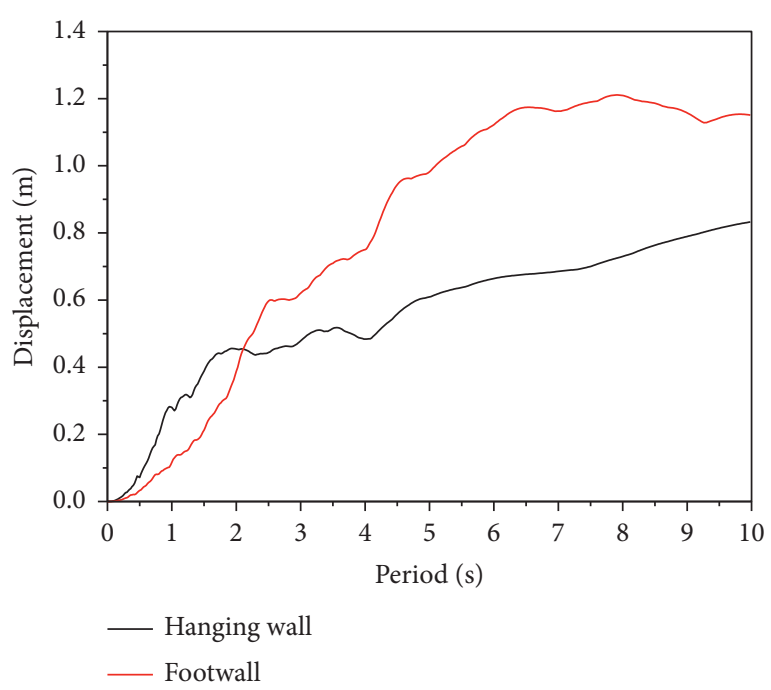

(b)

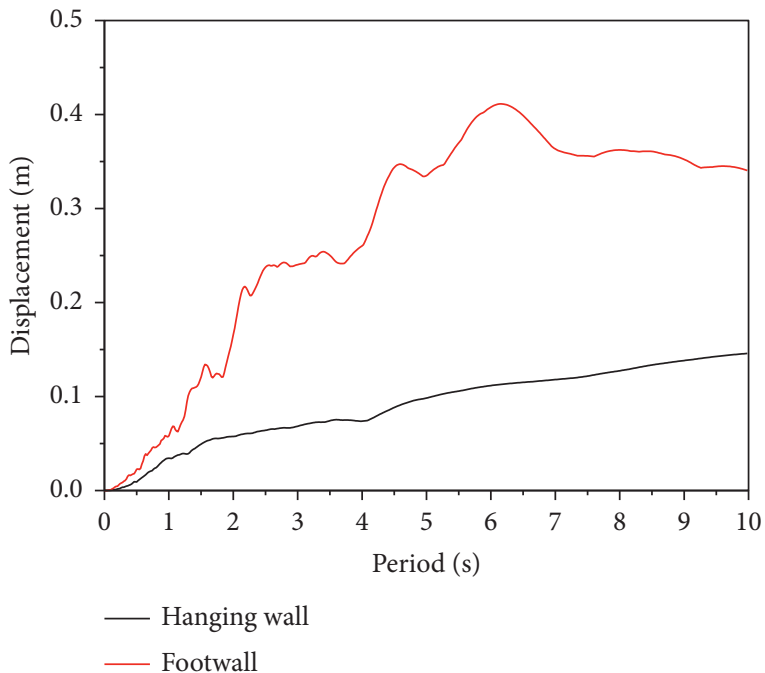

(d)

FIGURE 5: Response spectra of hanging wall and footwall waves: (a) acceleration spectra without amplitude modulation; (b) displacement spectra without amplitude modulation; (c) acceleration spectra with amplitude modulation; (d) displacement spectra with amplitude modulation.

motions are shown in Figure 10, which can be obtained that the spectra distributions of three kinds of ground motions are within $0-5 \mathrm{~Hz}, 0-2 \mathrm{~Hz}$, and $2-8 \mathrm{~Hz}$, respectively. Therefore, the spectra distributions of the three kinds of ground motions with and without velocity pulses are quite different. The energy distribution of ground motion with velocity pulse is mainly in low frequency, while it is mainly in medium-high frequencies in nonspeed pulse.

The average response spectra of ground motions with forward-directivity velocity pulse, fling-step velocity pulse, and nonspeed pulse are shown in Figure 11. It can be obtained from Figures 11(a) and 11(b) that to the ground motions without amplitude modulation, the average acceleration spectra of the ground motion with nonspeed pulse are the largest, and it is the smallest with the forwarddirectivity velocity pulse when the period is smaller than
$0.95 \mathrm{~s}$. In addition, the acceleration spectra value of the ground motion with fling-step velocity pulse becomes the largest, and the value with forward-directional velocity pulse is the smallest when the period is within $0.95 \mathrm{~s}$ and $1.6 \mathrm{~s}$. More interestingly, the acceleration spectra value of the ground motion with speed pulse is larger than that with nonspeed pulse when the period is larger than $1.6 \mathrm{~s}$. Consequently, the seismic response spectra of near-fault ground motion with or without pulse are quite different. The influence of ground motion without velocity pulse on the structure with short period is quite great. While the pulse-like ground motions have great influence on the structure with long period, and the response spectra of the ground motion with fling-step velocity pulse are larger than those with forward-directivity velocity pulse. This consists well with the finding that fling-step ground motions cause 


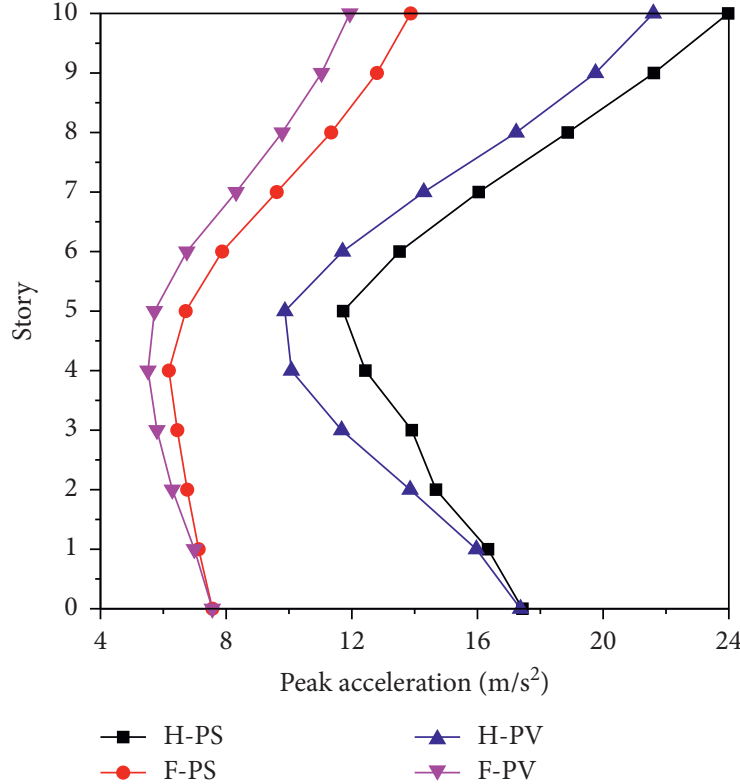

(a)

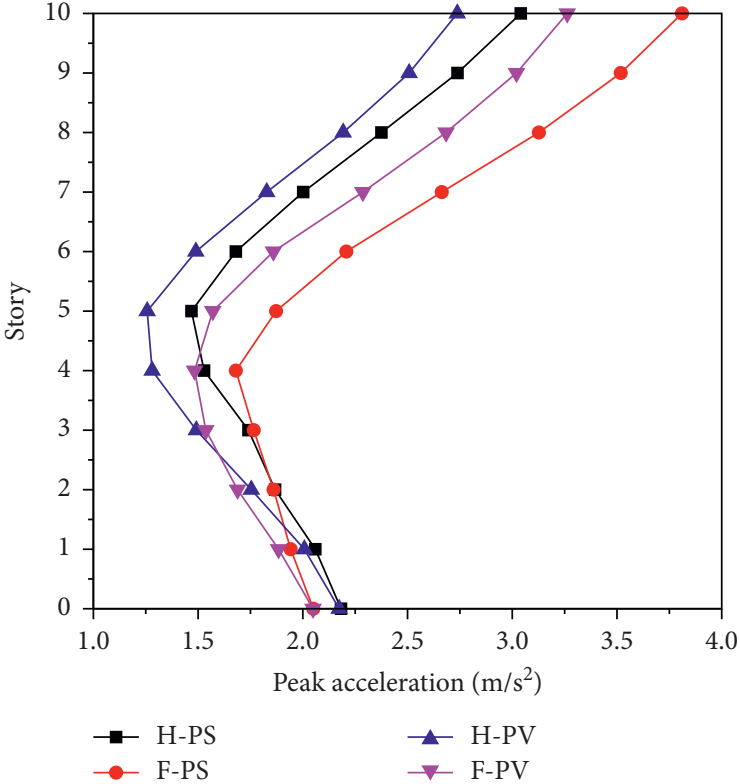

(b)

FIGURE 6: The average peak acceleration of the structure under the hanging wall and footwall seismic excitations: (a) without amplitude modulation; (b) with amplitude modulation. Note. H: hanging wall; F: footwall; PS: 10-story structure supported by pile group foundation on soft soil; PV: 10-story structure with viscous dampers supported by pile group foundation on soft soil.

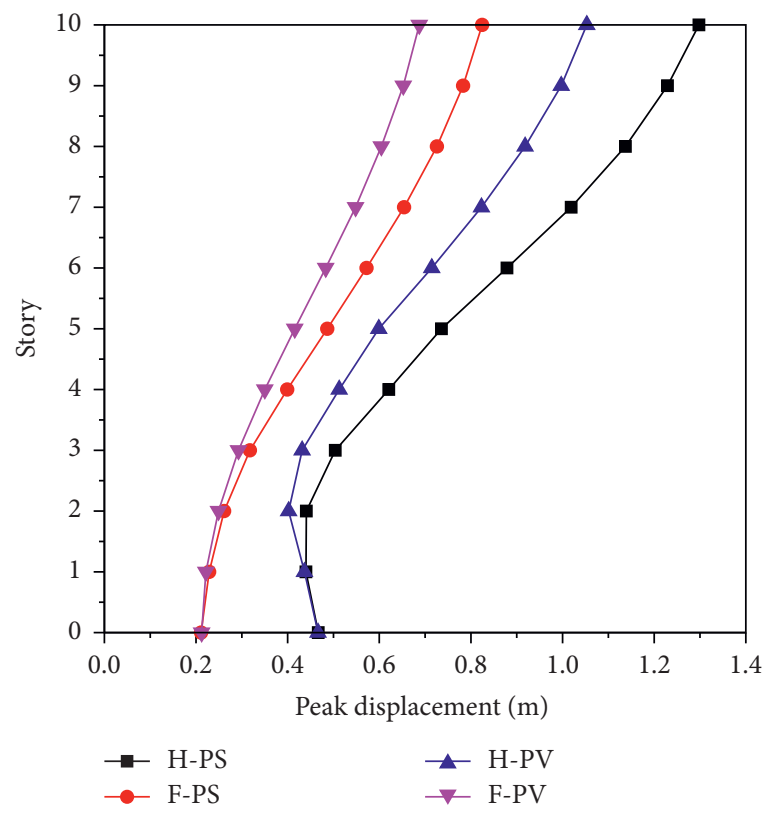

(a)

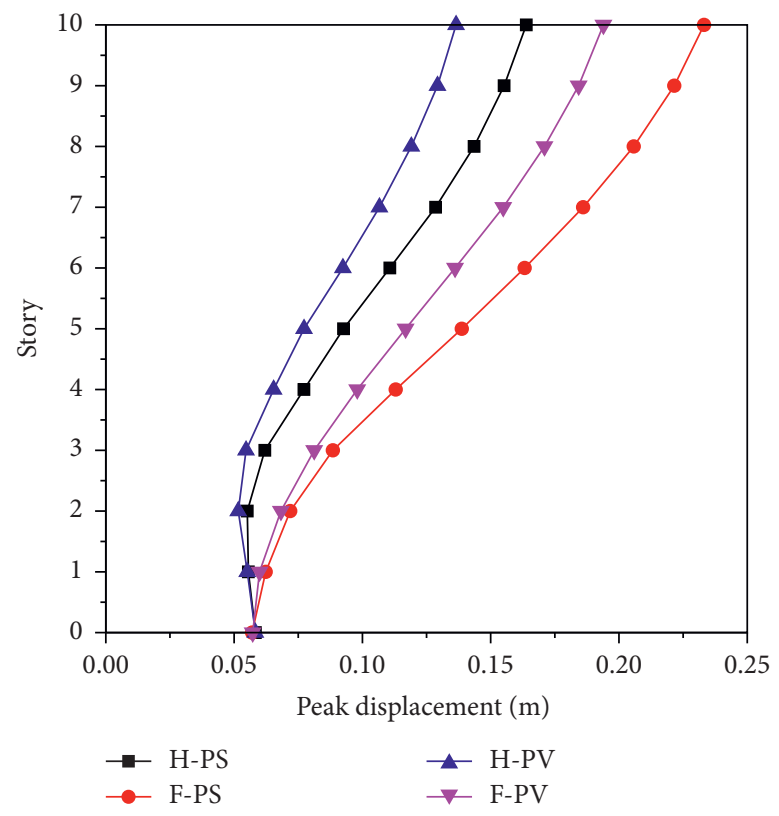

(b)

FIGURE 7: The average peak displacement of the structure under the hanging wall and footwall seismic excitations: (a) without amplitude modulation; (b) with amplitude modulation.

more damage to the structure than the forward-directivity records [13]. However, there exists a small difference between the response spectra of the ground motion with fling-step velocity pulse and forward-directivity velocity pulse when the PGA of the ground motion is modulated.
4.2. Acceleration of the Superstructure. The dynamic timehistory analysis is performed on the SSI system with and without viscous dampers subjected to the selected five forward-directivity velocity pulse records, five fling-step velocity pulse records, and five nonspeed pulse records. 


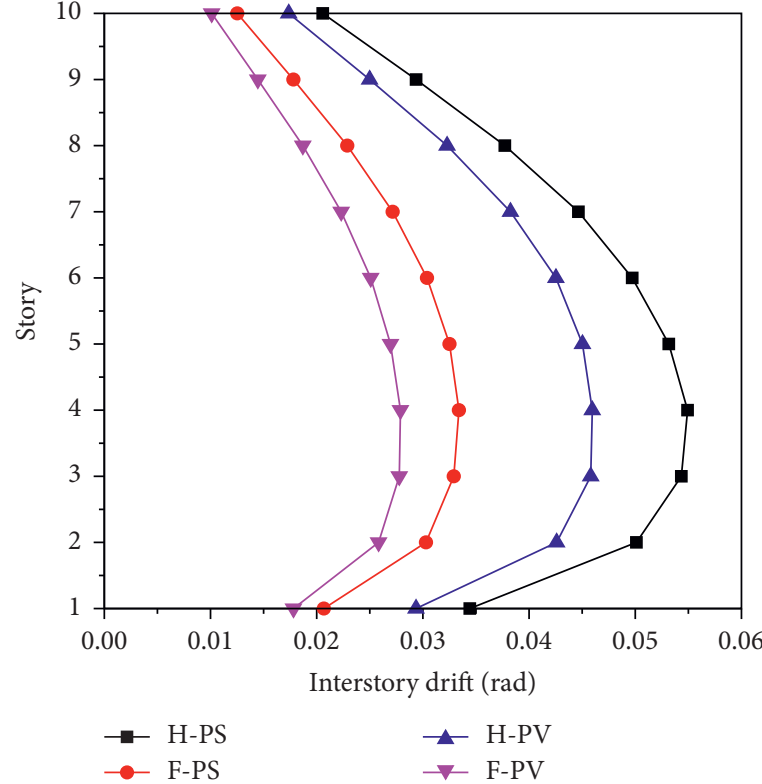

(a)

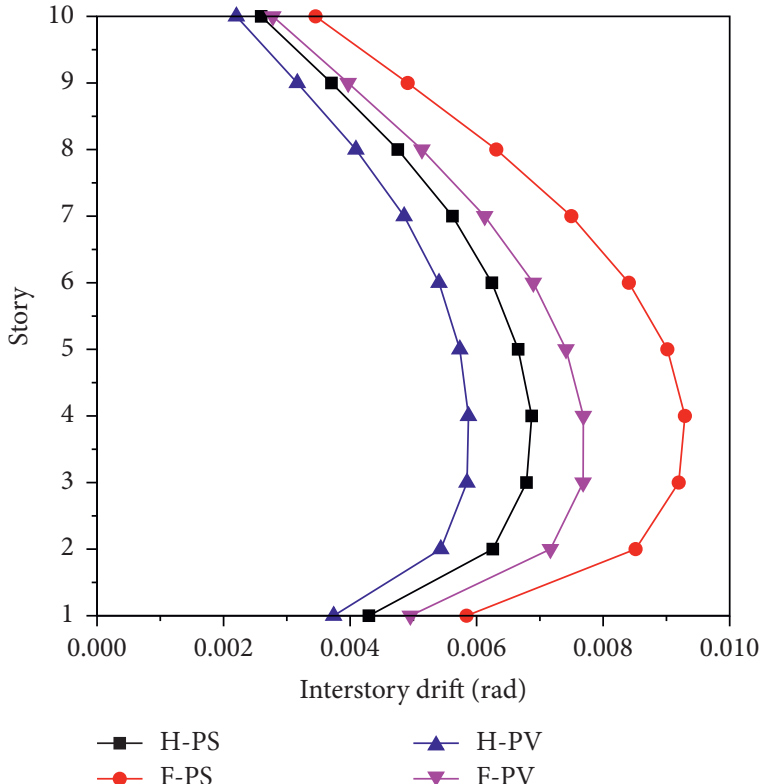

(b)

FIGURE 8: The average peak interstory drift of the structure under the hanging wall and footwall seismic excitations: (a) without amplitude modulation; (b) with amplitude modulation.

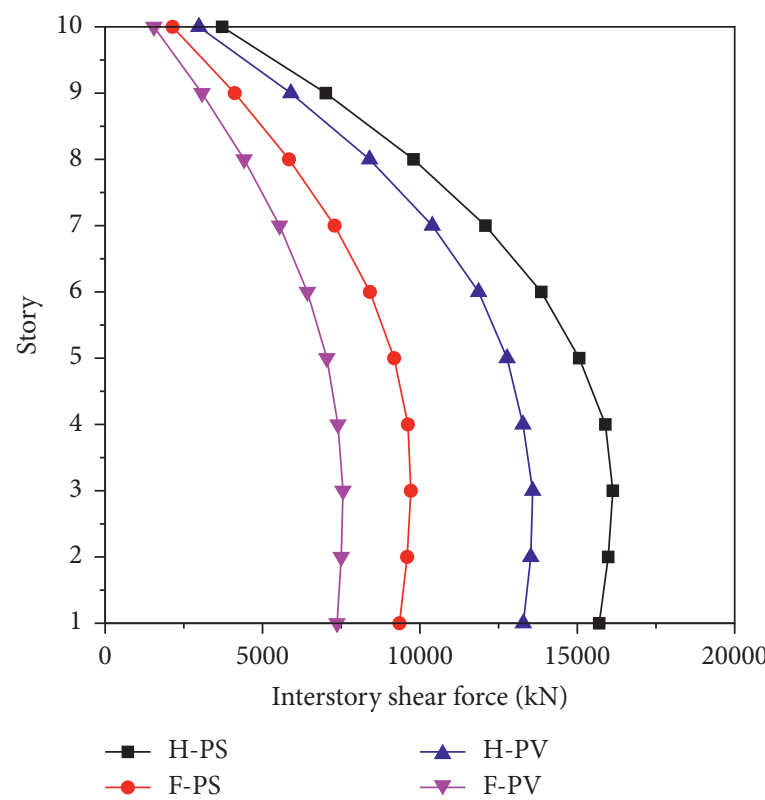

(a)

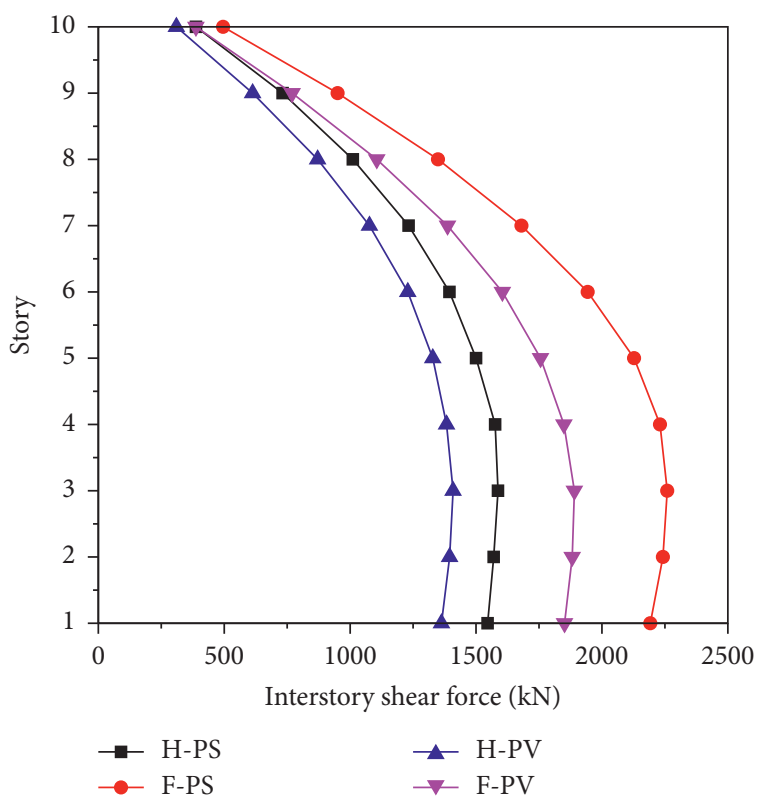

(b)

FIgURE 9: The average peak interstory shear force of the structure under the hanging wall and footwall seismic excitations: (a) without amplitude modulation; (b) with amplitude modulation.

TABLE 4: The selected ground motions with velocity pulses.

\begin{tabular}{|c|c|c|c|c|c|}
\hline Characteristics of ground motion & & & Station & & \\
\hline Forward-directional velocity pulse & TCU051-EW & TCU054-EW & TCU082-EW & TCU102-EW & TCU120-EW \\
\hline Fling-step velocity pulse & TCU052-NS & TCU052-EW & TCU075-EW & TCU067-EW & TCU068-EW \\
\hline Nonspeed pulse & TCU071-NS & TCU072-EW & TCU078-EW & TCU079-EW & TCU089-EW \\
\hline
\end{tabular}




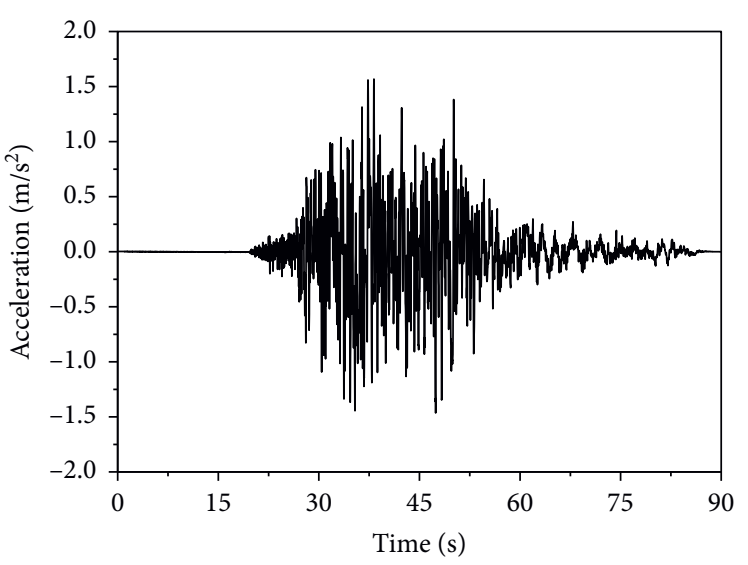

— TCU051E

(a)

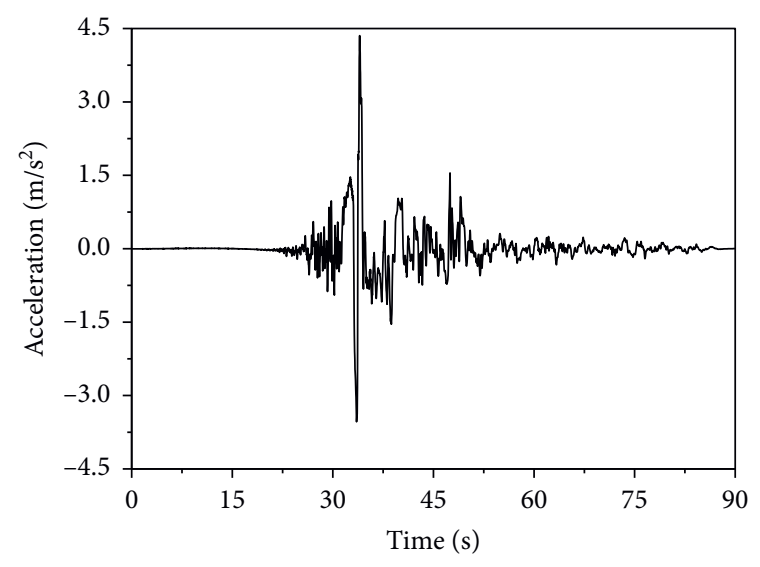

— TCU052N

(c)

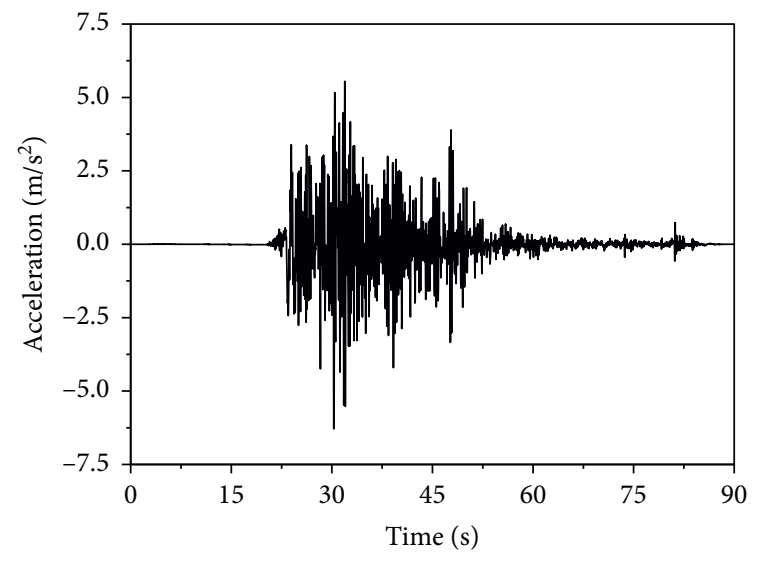

TCU071N

(e)

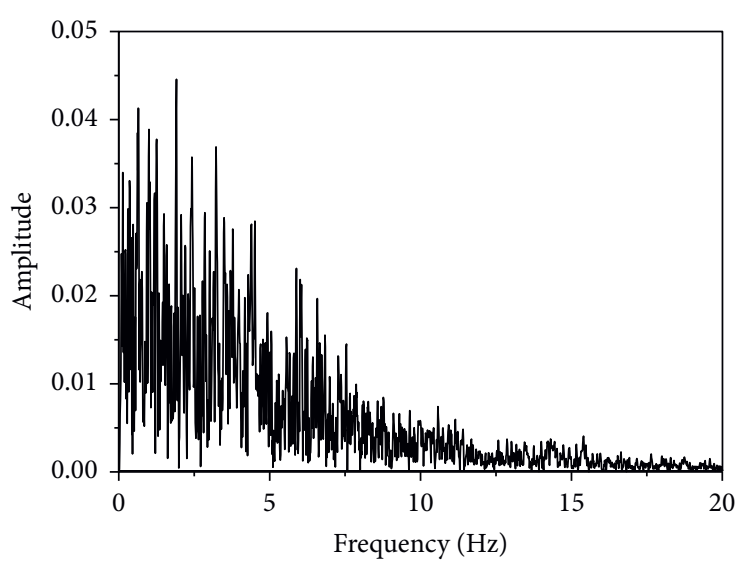

TCU051E

(b)

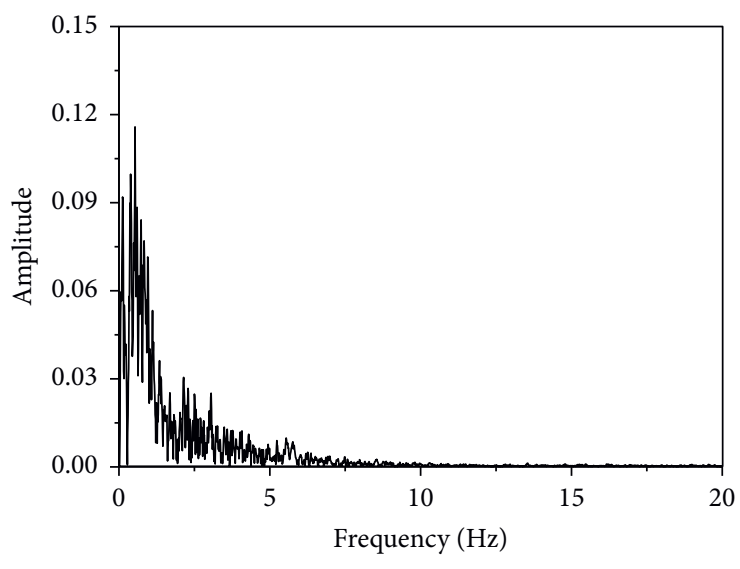

(d)

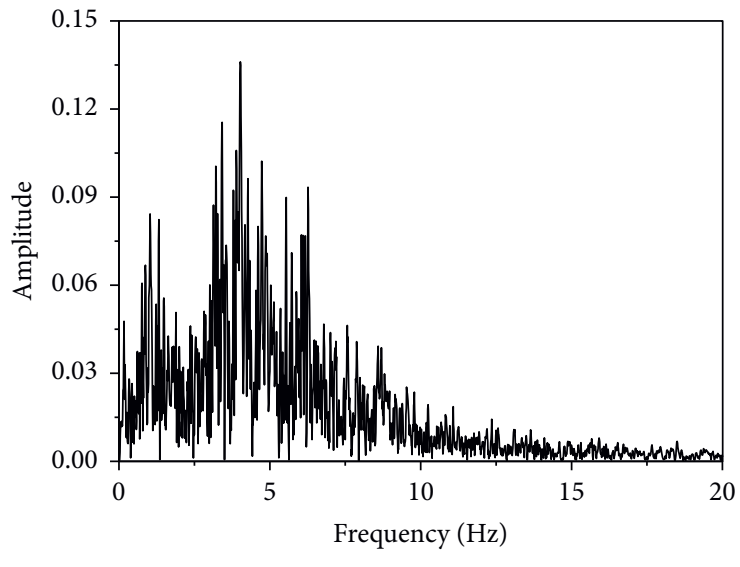

TCU071N

(f)

FIGURE 10: (a) The acceleration time-history of forward-directivity ground motion; (b) the corresponding Fourier spectra of forwarddirectivity ground motion; (c) the acceleration time-history of fling-step ground motion; (d) the corresponding Fourier spectra of fling-step ground motion; (e) the acceleration time-history of nonspeed ground motion; (f) the corresponding Fourier spectra of nonspeed ground motion.

Figure 12 shows the average peak acceleration responses of the superstructure under the three kinds of selected ground motions without amplitude modulation. It can be obtained from Figures 12(a) and 12(b) that the peak acceleration of the structure subjected to the fling-step velocity pulse excitations is the largest, and it is the smallest under the 


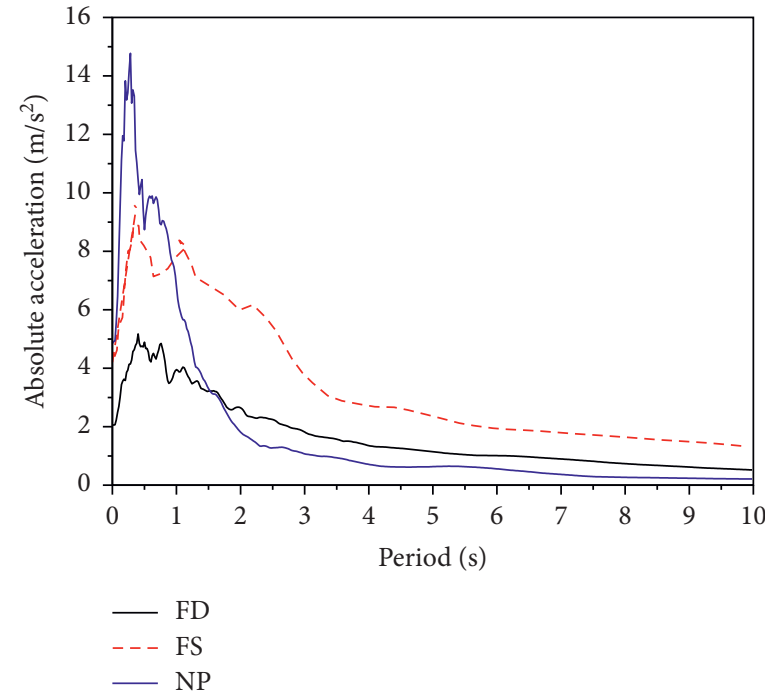

(a)

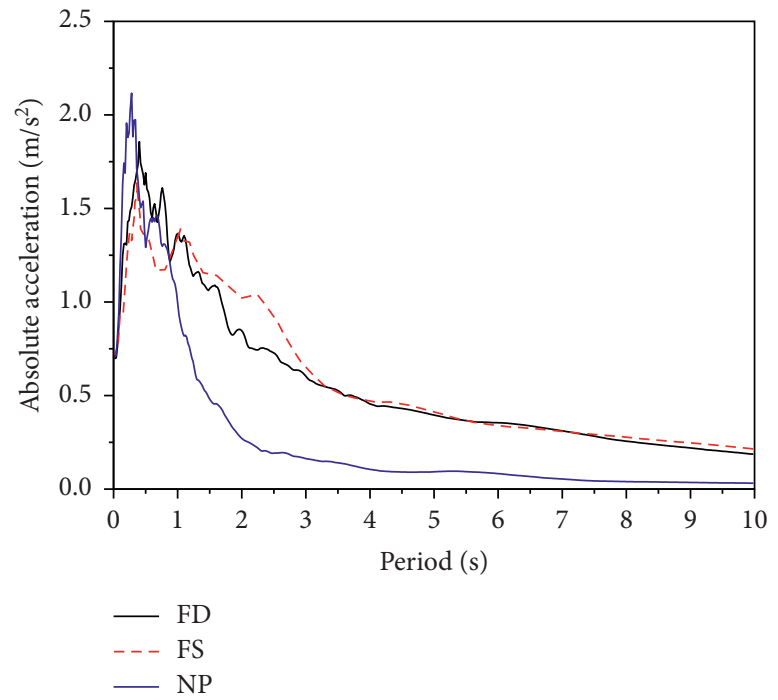

(c)

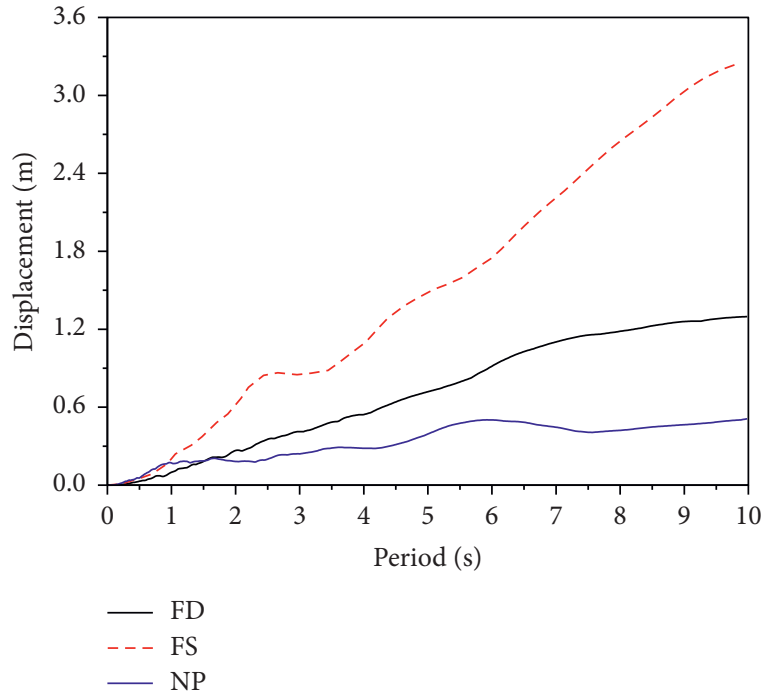

(b)

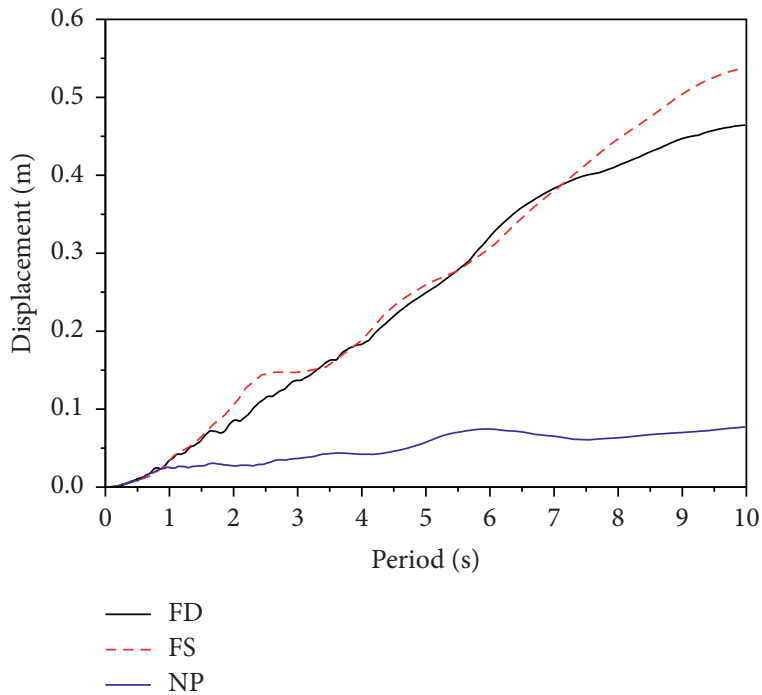

(d)

FIGURE 11: The response spectra of ground motions with forward-directional velocity pulse, fling-step velocity pulse, and nonspeed pulse: (a) the acceleration spectra without amplitude modulation; (b) the displacement spectra without amplitude modulation; (c) the acceleration spectra with amplitude modulation; (d) the displacement spectra with amplitude modulation. Note. FD is the forward-directivity velocity pulse; FS is the fling-step velocity pulse; NP is nonspeed pulse.

excitations with forward-directivity velocity pulse, not the nonspeed pulse. The reason is that the seismic responses of the structure under the excitations with or without velocity pulse are related to the dynamic characteristics of the structure and the features of the response spectra of the selected ground motions. The peak acceleration of the structure has been decreased by the viscous dampers effectively, as shown in Figure 12(c).

4.3. Displacement of the Superstructure. Figure 13 shows the average peak displacement of the superstructure under the three kinds of selected near-fault ground motions without amplitude modulation, which can be obtained that the peak displacement of the structure subjected to the excitations with fling-step velocity pulse is the largest. Moreover, there is not an obvious difference in the displacements under the excitations with forward-directional velocity pulse and nonspeed pulse, which is different from the conclusion of acceleration. The reason is that the pulse-like ground motions generate larger displacement to the structure compared with the nonpulse ground motions [13]. The peak displacement has been reduced by the viscous dampers effectively, as shown in Figure 13(c).

4.4. Interstory Drift of the Superstructure. The average peak interstory drifts of the superstructure under the three kinds of selected near-fault ground motions without amplitude are shown in Figure 14. It highlights that the peak interstory 


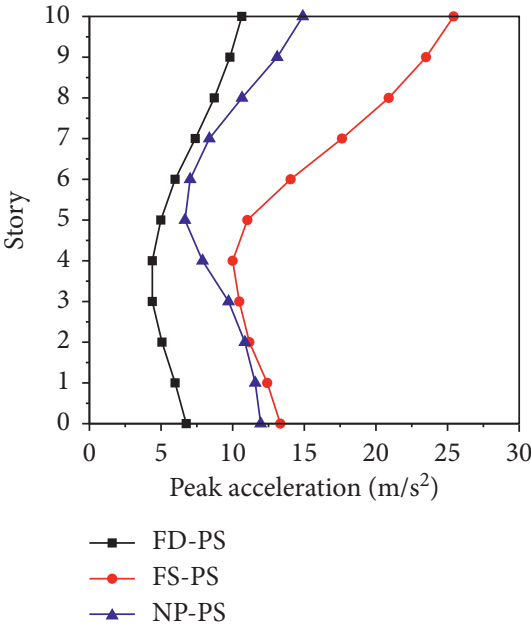

(a)

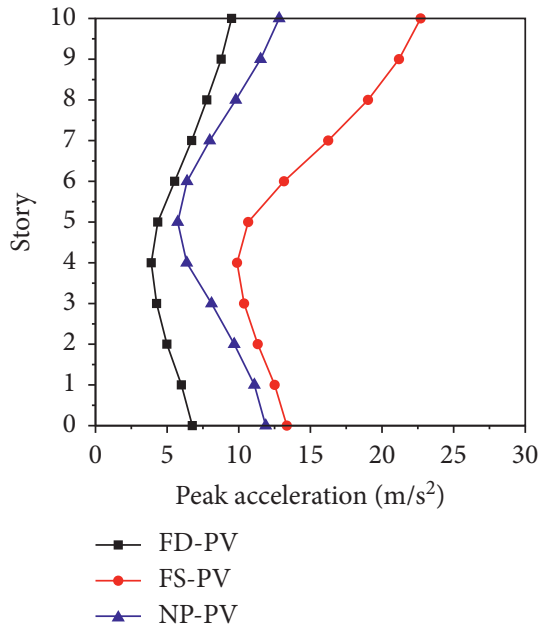

(b)

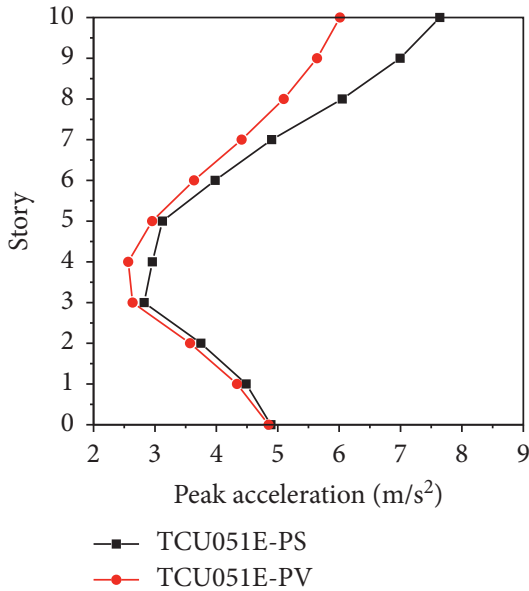

(c)

FIGURE 12: The average peak acceleration of the structure under seismic excitations with velocity pulse: (a) the SSI system without viscous dampers; (b) the SSI system with viscous dampers; (c) the ground motion of TCU051E.

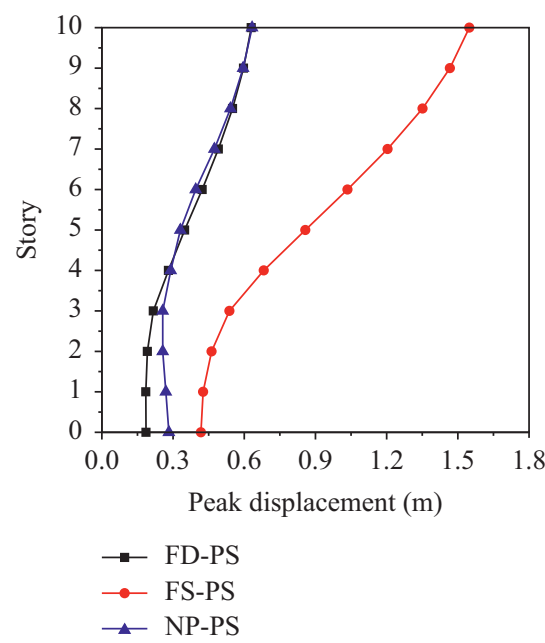

(a)

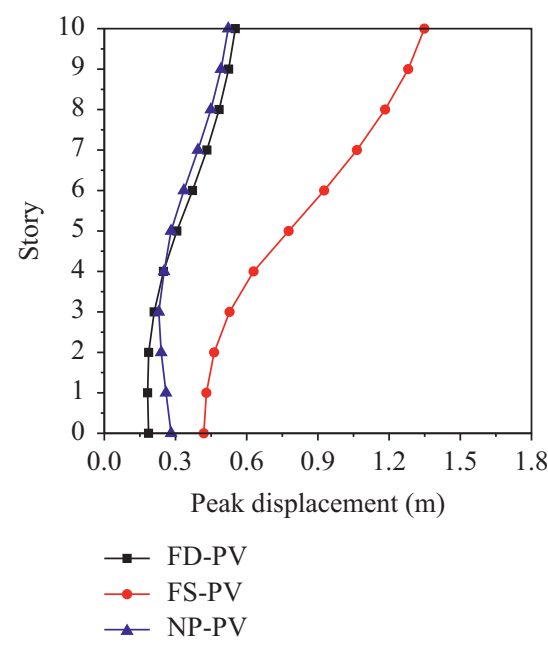

(b)

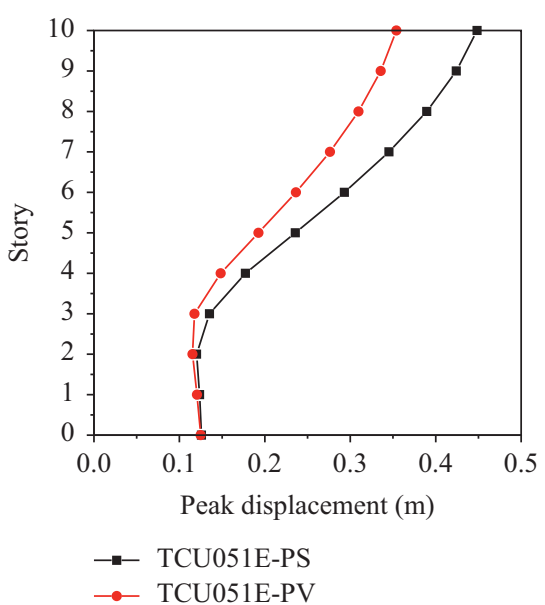

(c)

FIGURE 13: The average peak displacement of the structure under seismic excitations with velocity pulse: (a) the SSI system without viscous dampers; (b) the SSI system with viscous dampers; (c) the ground motion of TCU051E.

drift of the structure under the excitations with fling-step velocity pulse is the largest. Moreover, the interstory drift of the structure under the excitations with nonspeed pulse is a little larger than that with forward-directivity velocity pulse. The peak interstory drift has been decreased by the viscous dampers effectively, as shown in Figure 14(c).

4.5. Interstory Shear Force of the Superstructure. Figure 15 presents the average peak interstory shear force of the superstructure under the three kinds of selected near-fault ground motions without amplitude. It is suggested that the peak interstory shear force of the structure subjected to the excitations with fling-step velocity pulse is the largest.
Moreover, the interstory shear force of the structure under the excitations with nonspeed pulse is a little larger than that with forward-directional velocity pulse. This agrees with the conclusion of interstory drift. The viscous dampers mitigate the interstory shear force effectively.

It is confirmed that the near-fault ground motion without velocity pulse has little influence on the seismic response of the structure with energy dissipation devices including the SSI effect. Compared with the velocity pulse generated by the two kinds of effects, the performance of the structure with viscous dampers is more influenced by the ground motions with fling-step than that with forwarddirectivity effect. Consequently, the pulse with fling-step effect is more dangerous to the dissipation structure 


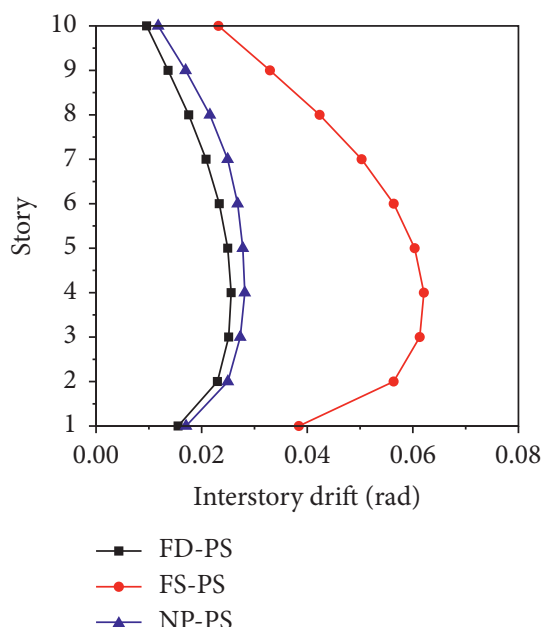

(a)

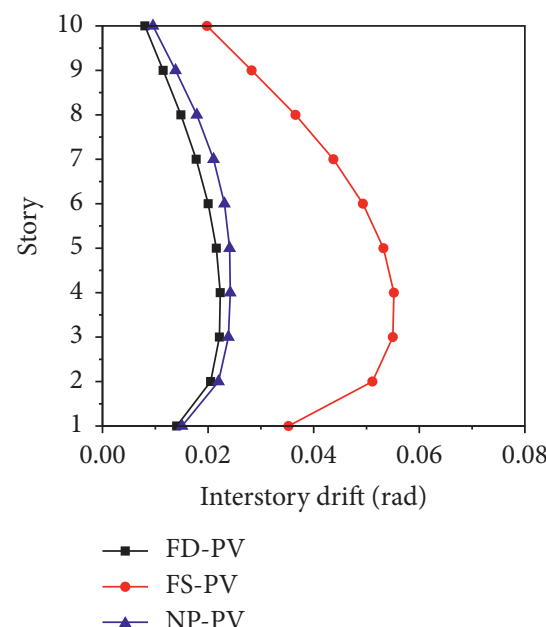

(b)

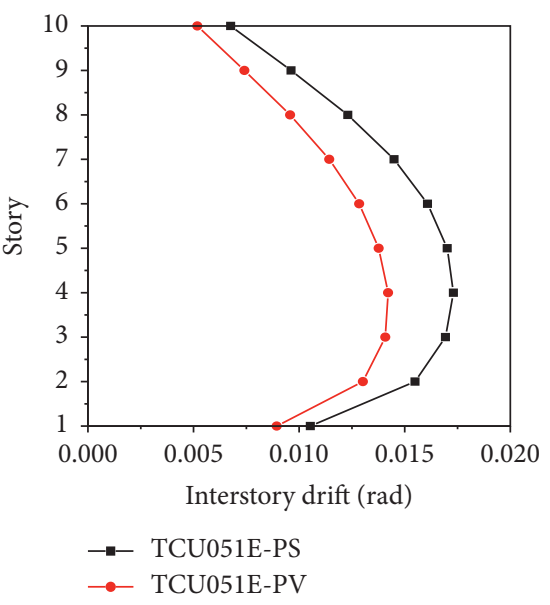

(c)

FIGURE 14: The average peak interstory drift of the structure under seismic excitations with velocity pulse: (a) the SSI system without viscous dampers; (b) the SSI system with viscous dampers; (c) the ground motion of TCU051E.

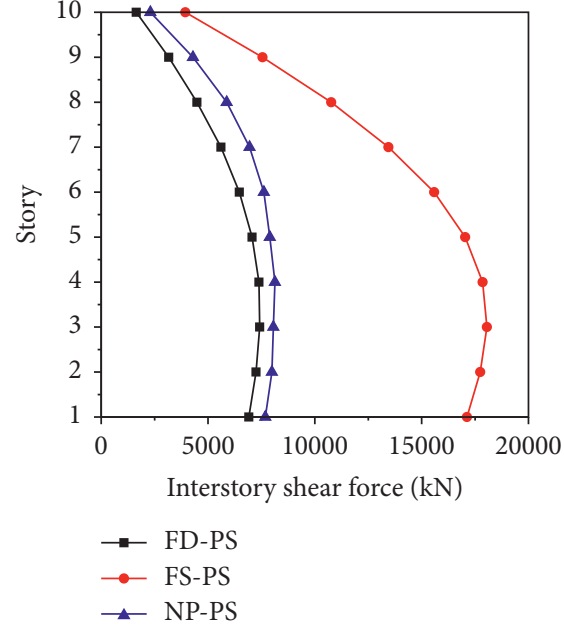

(a)

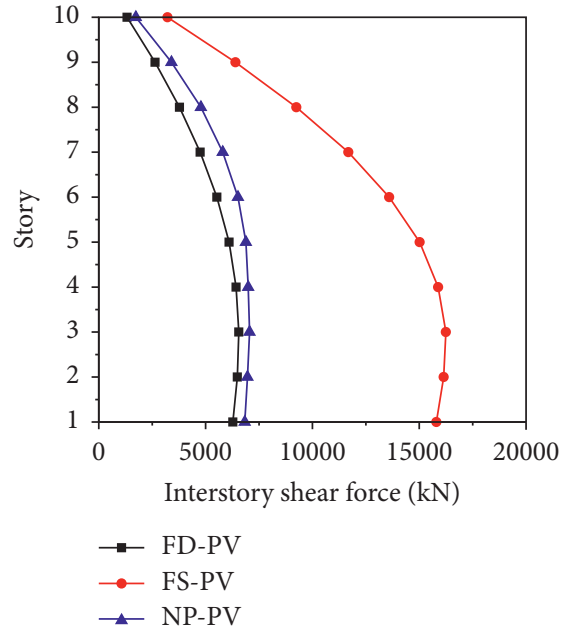

(b)

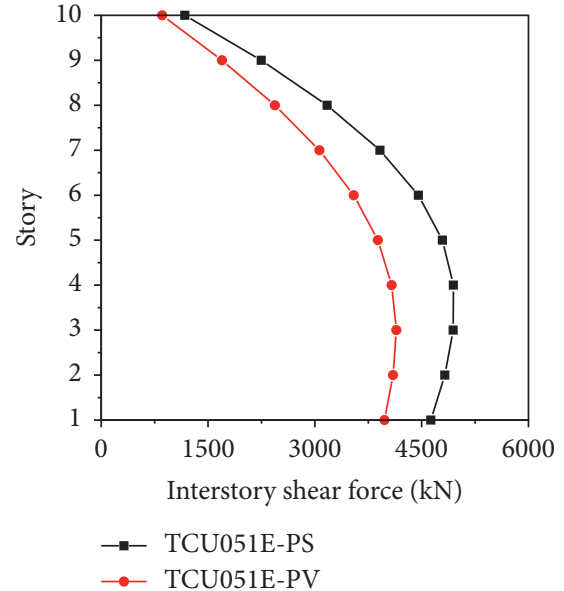

(c)

FIGURE 15: The average peak interstory shear force of the structure under seismic excitations with velocity pulse: (a) the SSI system without viscous dampers; (b) the SSI system with viscous dampers; (c) the ground motion of TCU051E.

TABLE 5: The selected forward-directivity ground motions.

\begin{tabular}{|c|c|c|c|c|c|c|c|c|}
\hline Characteristics of ground motion & & & & Sta & & & & \\
\hline Horizontal component & TCU065 & TCU074 & TCU075 & TCU079 & TCU089 & TCU102 & TCU120 & E-W \\
\hline Parallel component & TCU065 & TCU074 & TCO075 & TCU079 & TCU089 & TCU102 & TCU120 & N-S \\
\hline
\end{tabular}

considering the SSI effect. While the ground motions with forward-directivity velocity pulses have little influence on the SSI system with viscous dampers. This is different from the conclusions obtained from the isolated structure [49]. The reason is that the influences of the ground motions with velocity pulse on the seismic responses of the structure have related to the dynamic characteristics of itself, frequency components, and the response spectra characteristics of the selected ground motions [2].

\section{Influence of Forward-Directivity Effect on SSI System with Viscous Dampers}

When the rupture propagates along an observation point on the fault surface and the propagation velocity is close to the 


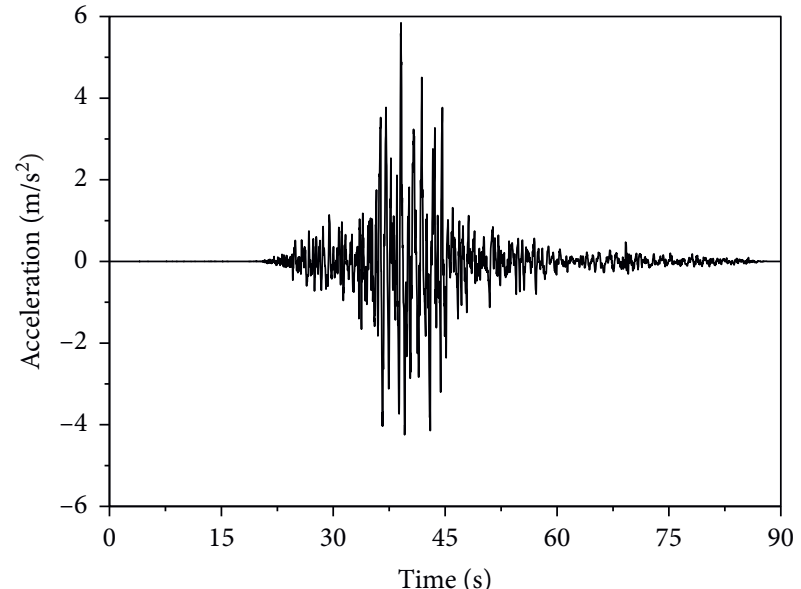

— TCU074E

(a)

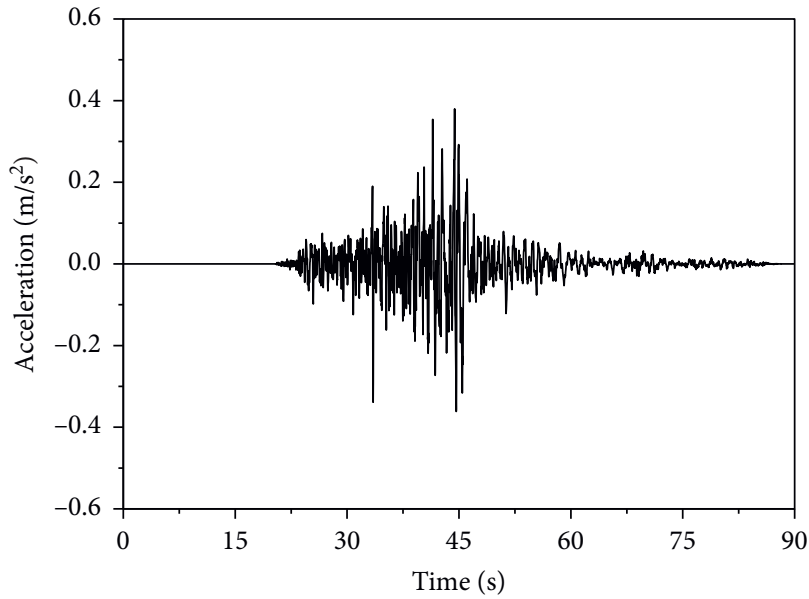

TCU074N

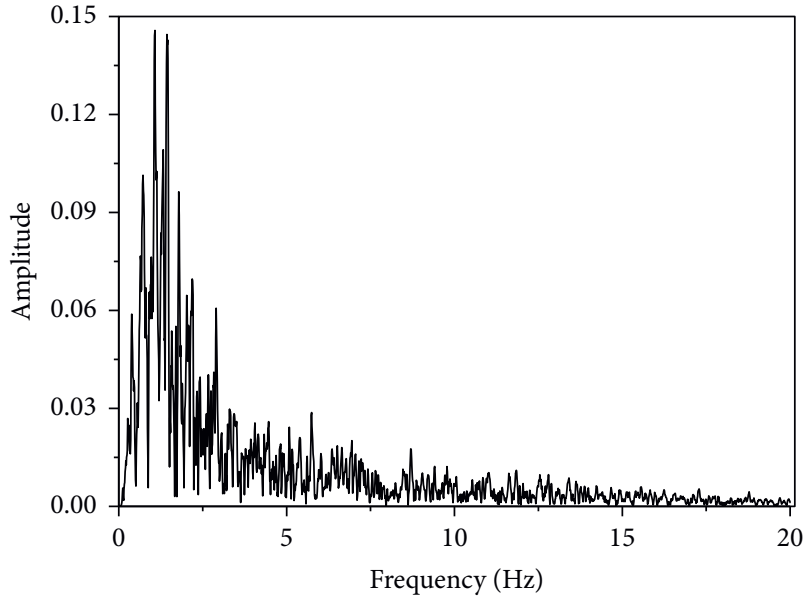

TCU074E

(b)

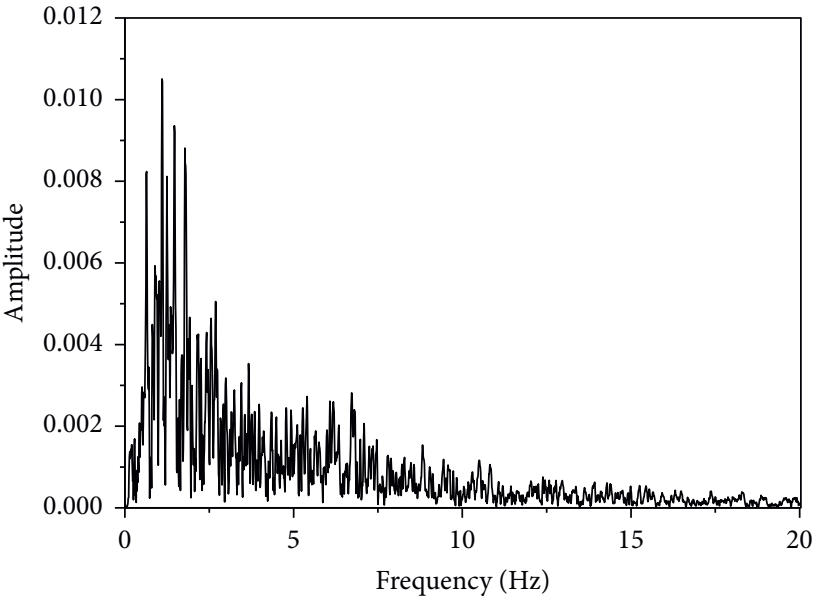

TCU074N

(c)

(d)

Figure 16: (a) The acceleration time-history of horizontal component ground motion; (b) the corresponding Fourier spectra of horizontal component ground motion; (c) the acceleration time-history of parallel component ground motion; (d) the corresponding Fourier spectra of parallel component ground motion.

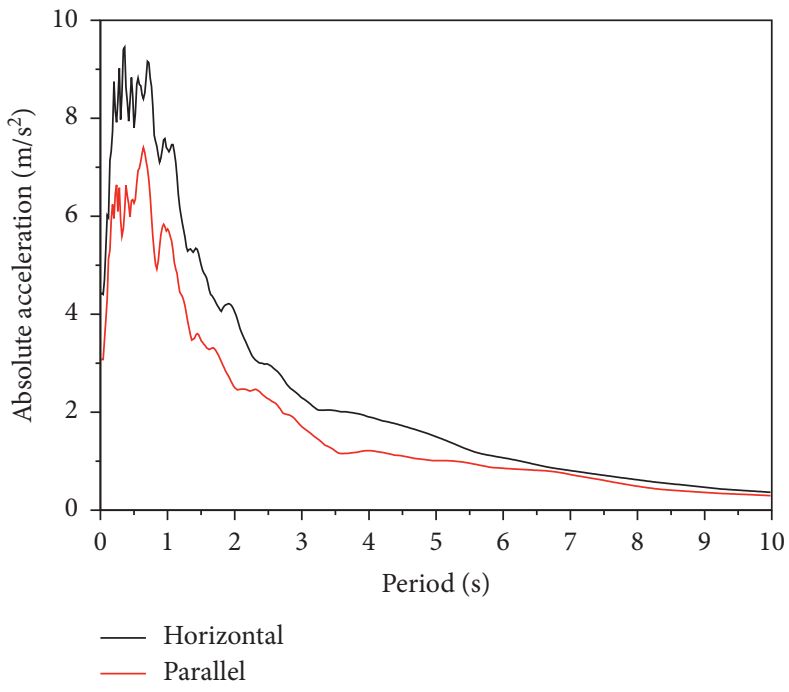

(a)

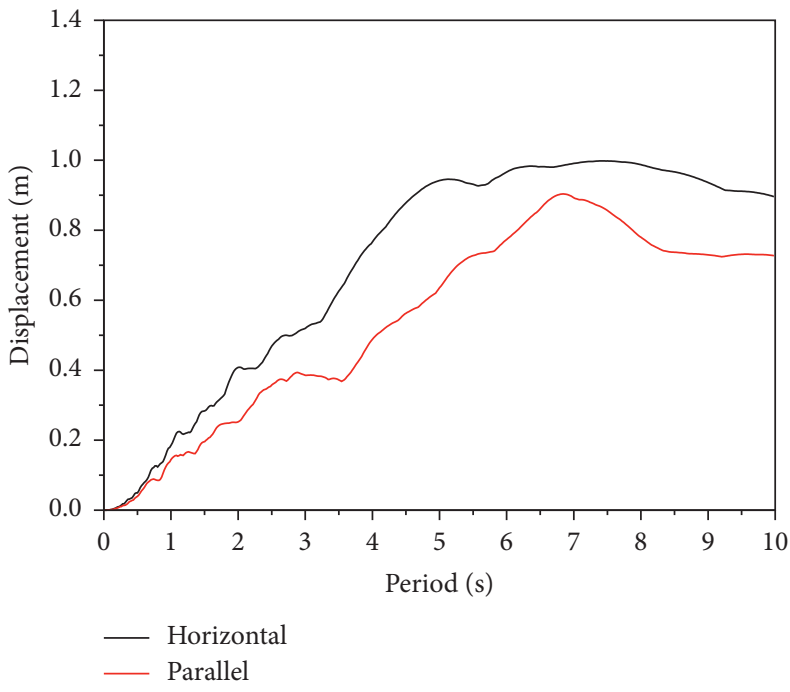

(b)

FIgURE 17: Continued. 


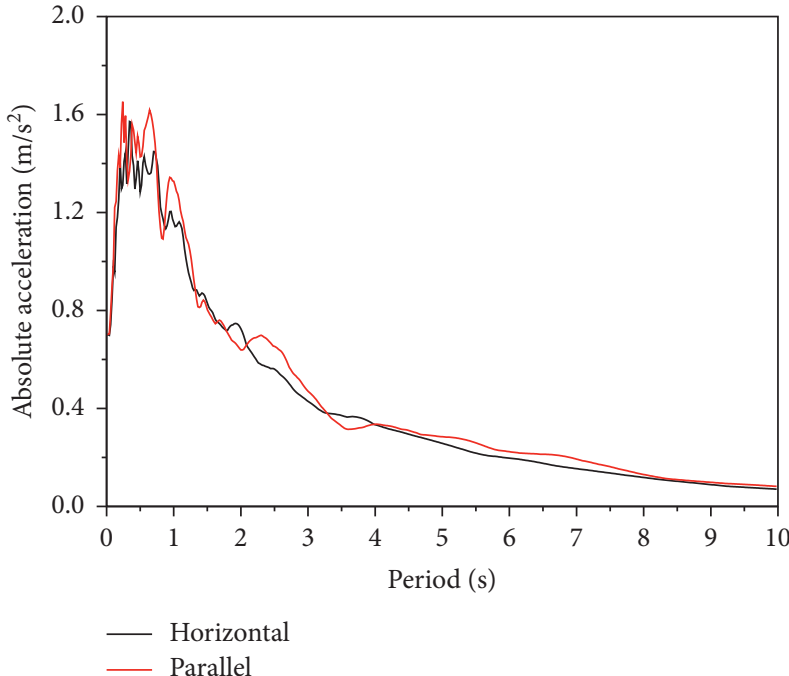

(c)

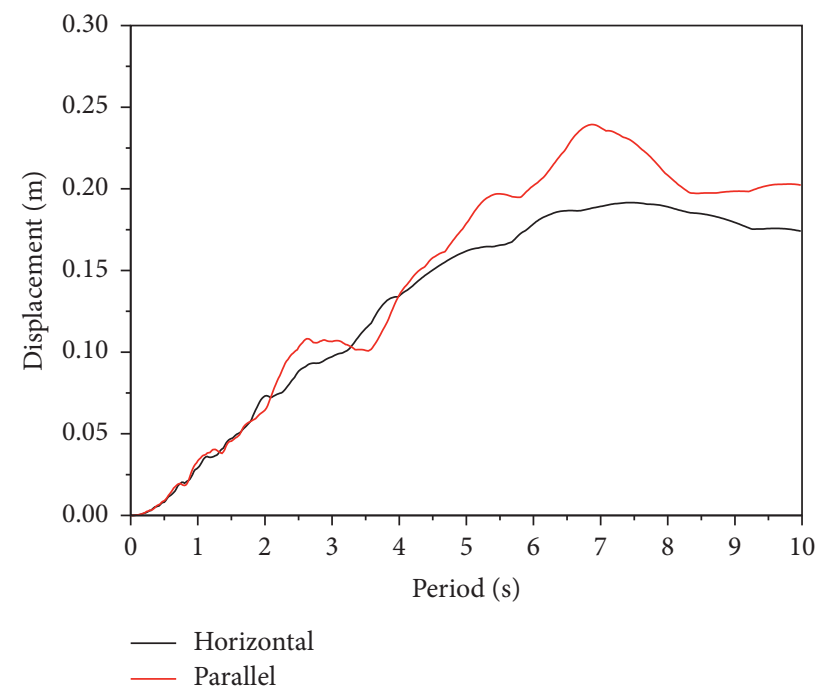

(d)

FIGURE 17: (a) Acceleration spectra of horizontal component without amplitude modulation; (b) displacement spectra of horizontal component without amplitude modulation; (c) acceleration spectra of parallel component with amplitude modulation; (d) displacement spectra of parallel component with amplitude modulation.

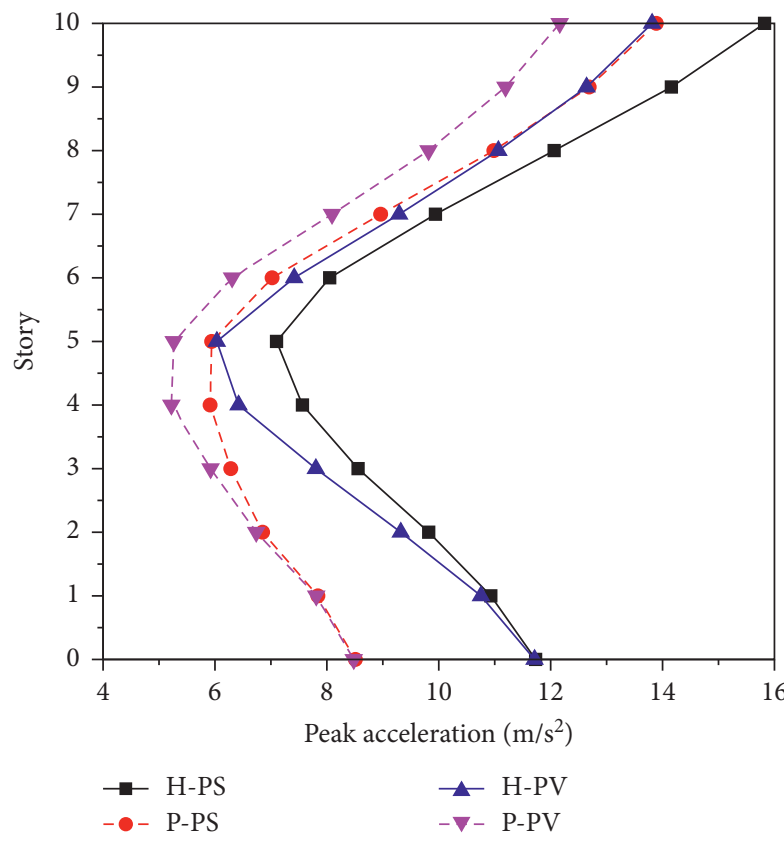

(a)

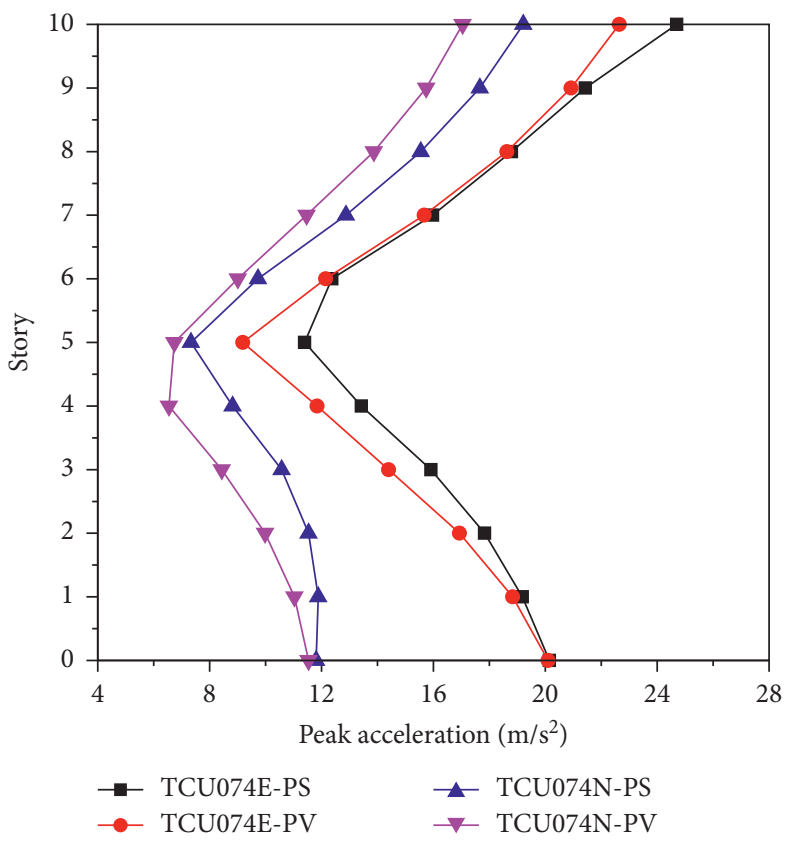

(b)

Figure 18: (a) The average peak acceleration of the structure under the horizontal component and parallel component of near-fault ground motion; (b) the peak acceleration of the structure under the ground motion of TCU074. Note. $\mathrm{H}$ and $\mathrm{P}$ are the horizontal and parallel components of near-fault ground motions, respectively.

shear wave velocity of the soil in the process of rupture, then most of the energy radiated from the fault surface is transferred to the observation point at the same time approximately. Therefore, a long period and large amplitude pulse is formed at this point. This is so-called directivity effect of rupture propagation [50]. According to the relationship between the direction of fault rupture and the site, the directional effect can be divided into three types: forward-directivity effect, post-directivity effect, and neutral directivity effect. Moreover, the ground motions with forward-directivity effect may aggravate the damage to the structure in practical engineering. Therefore, the directional 

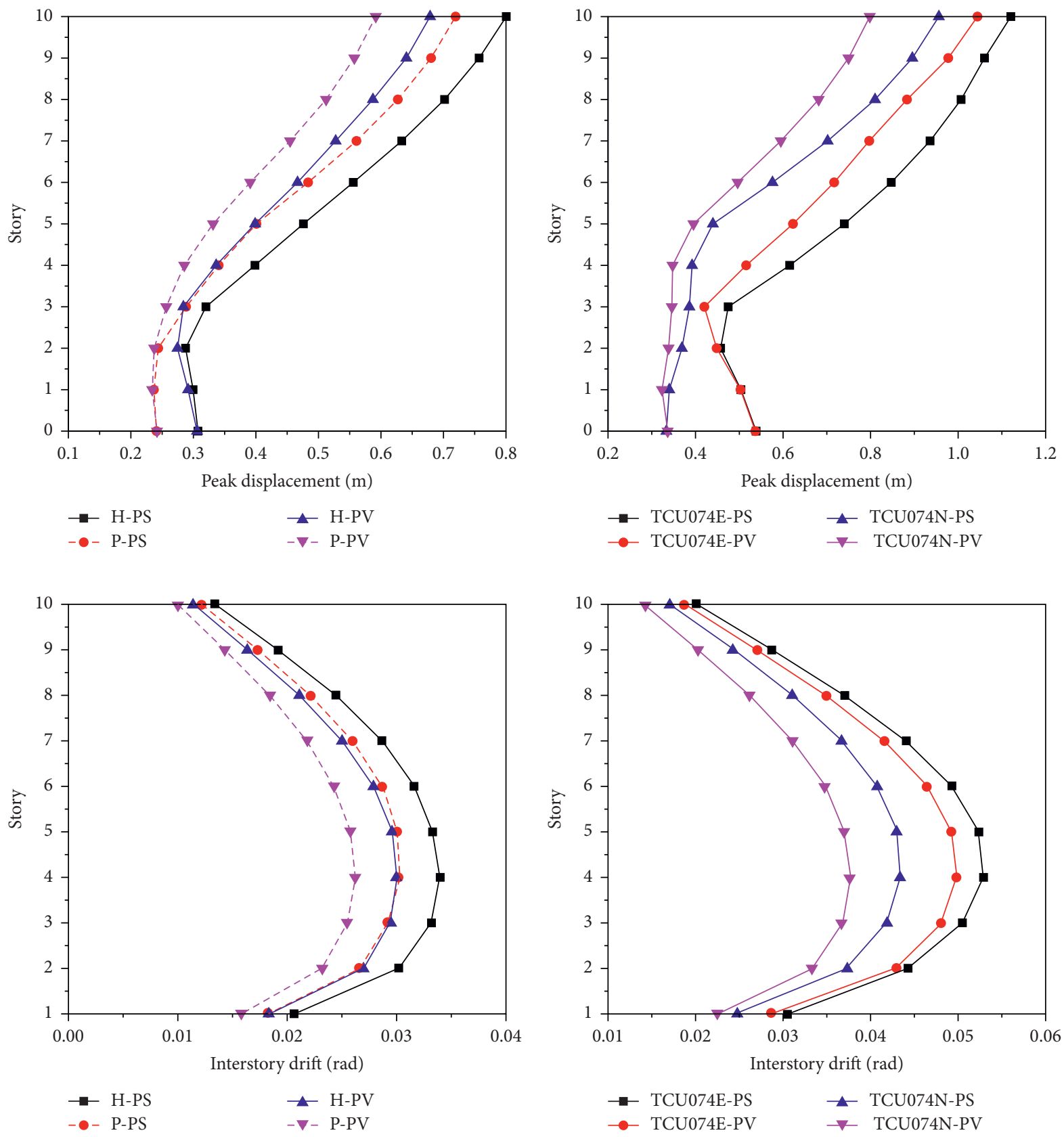

(a)

(b)

FIGURE 19: (a) The average peak displacement of the structure under the horizontal component and parallel component of near-fault ground motion; (b) the peak displacement of the structure under the ground motion of TCU074.

effect usually refers to the forward-directivity effect. Then, this section focuses on the forward-directivity effect, mainly to investigate the influence of the ground motions with the horizontal component and parallel component of the normal fault on the SSI system with energy dissipation devices.

5.1. Forward-Directivity Ground Motions. The Cagerpu fault, the seismic fault of the Chi-Chi earthquake in Taiwan, is a typical thrust fault. The horizontal component of this normal fault is the east-west component (E-W component), and the parallel component is the north-south component (N-S component). This section is mainly studied on the influence of E-W and N-S horizontal waves selected from the same station on the seismic responses of the structure with viscous dampers including SSI effect. The selected seismic records are located in front of the fault, and the fault distances are all within $20 \mathrm{~km}$. The PGA and PGV are larger than $100 \mathrm{~cm} / \mathrm{s}^{2}$ and $40 \mathrm{~cm} / \mathrm{s}$, respectively. Moreover, the ratio of the spectra acceleration of the horizontal component to the parallel component is greater than 1 at the point of period $3 \mathrm{~s}$, and the ratio of the peak velocities of the two components is 


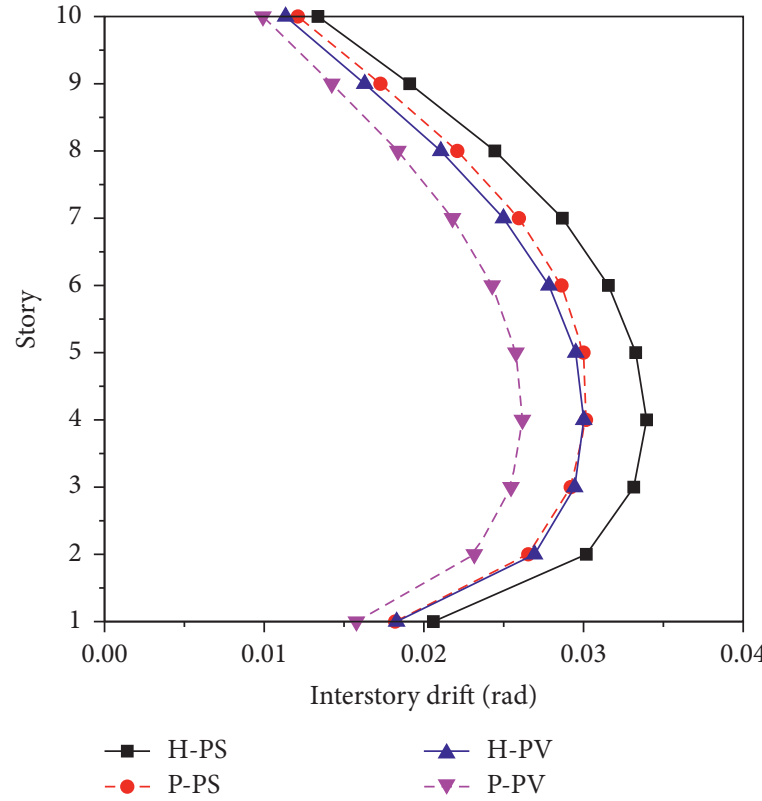

(a)

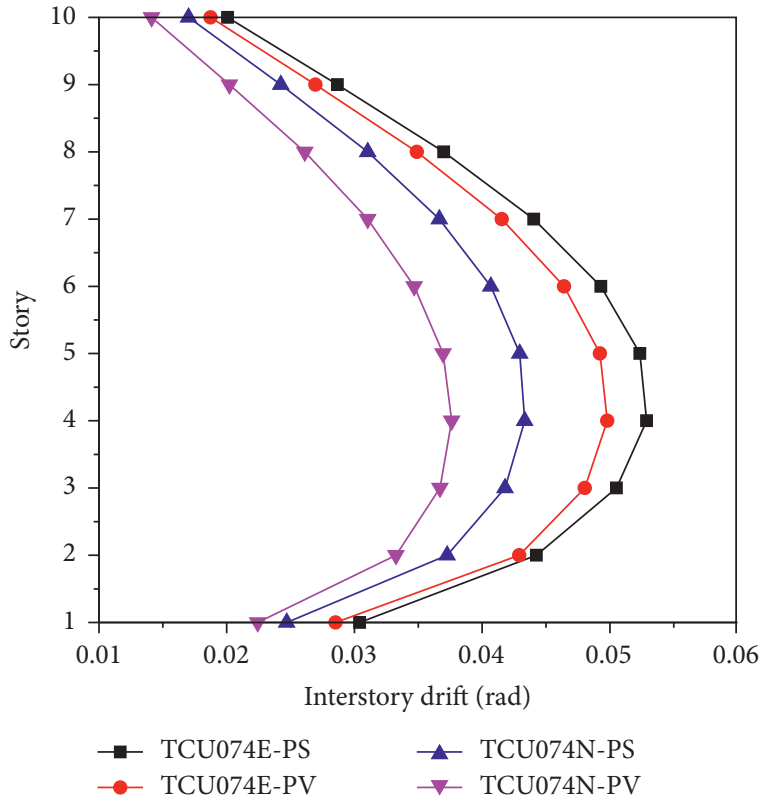

(b)

FIgURE 20: (a) The average peak interstory drift of the structure under the horizontal component and parallel component of near-fault ground motion; (b) the peak interstory drift of the structure under the ground motion of TCU074.

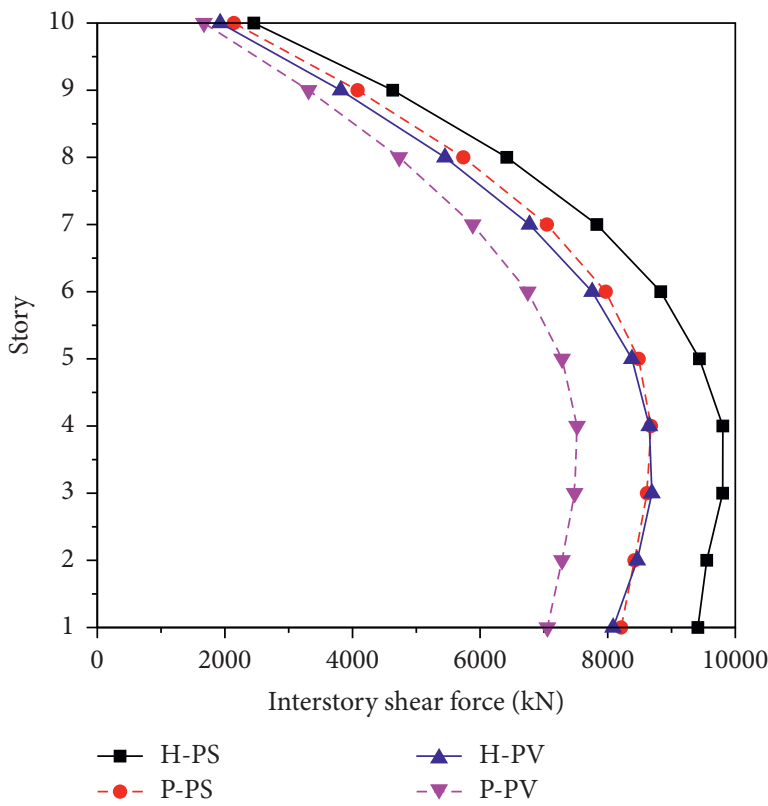

(a)

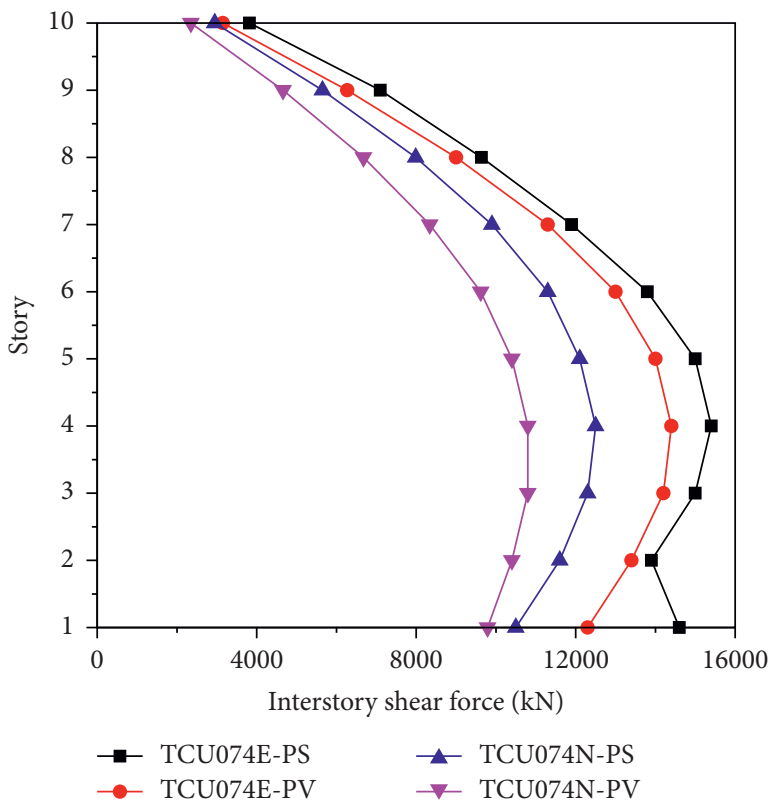

(b)

FIGURE 21: (a) The average peak interstory shear force of the structure under the horizontal component and parallel component of near-fault ground motion; (b) the peak interstory shear force of the structure under the ground motion of TCU074.

larger than or close to 1 . The station information of the selected seismic records with forward-directional effect is shown in Table 5.

Two acceleration time-histories and their corresponding Fourier spectra of the two kinds of ground motions are shown in Figure 16. It can be obtained that the spectra distributions of horizontal and parallel ground motions are both within $0-5 \mathrm{~Hz}$, which reveals that the two components of near-fault ground motion may be unfavorable to the structure with medium-long period.

The average response spectra of the ground motion from the horizontal component and parallel component are shown in Figure 17, which indicates that the average acceleration and displacement spectra of the horizontal 
component are both larger than those of the parallel component without the amplitude modulation. This demonstrates that the horizontal component of the forwarddirectivity ground motions has a great influence on the structure. However, the response spectra of the parallel components become a little larger than those of the horizontal component with amplitude modulation.

5.2. Acceleration of the Superstructure. The dynamic timehistory analysis is performed on the SSI system with and without viscous dampers subjected to the selected seven horizontal component ground motions and seven parallel component ground motions. Figure 18(a) shows the average peak acceleration responses of the superstructure under the selected ground motions without amplitude modulation. Figure 18(b) shows the peak acceleration of the structure under the excitation of TCU074E/N. It can be obtained that the peak acceleration of the structure under horizontal component excitation is larger than that of the parallel component, indicating that the horizontal component of near-fault ground motion has a greater influence on the seismic response of the structure than the parallel component. In addition, the acceleration of the structure has been decreased by the viscous dampers effectively.

5.3. Displacement of the Superstructure. Figures 19(a) and 19(b) show the average peak displacement responses of the superstructure under the selected ground motions without amplitude modulation and the peak displacement of the structure under the excitation of TCU074E/N, respectively. It is confirmed that the peak displacement of the structure under the excitation of the horizontal component of nearfault ground motion is larger than that of the parallel component. In addition, the viscous damper plays a good role in reducing the peak displacement of the structure, which is better than in mitigating the acceleration responses.

5.4. Interstory Drift of the Superstructure. The average peak interstory drifts of the superstructure under the selected ground motions without amplitude modulation and the peak interstory drifts of the structure under the excitation of TCU074E/N are shown in Figures 20(a) and 20(b), respectively. It suggests that the peak interstory drift of the structure under the excitation of the horizontal component of near-fault ground motion is larger than that of the parallel component. The viscous damper plays a good role in decreasing the peak interstory drifts of the structure.

5.5. Interstory Shear Force of the Superstructure. The average peak interstory shear forces of the superstructure under the selected ground motions without amplitude modulation and the peak interstory shear forces of the structure under the excitation of TCU074E/N are shown in Figures 21(a) and 21(b), respectively. The results illustrated that the peak interstory shear force of the structure under the excitation of the horizontal component of near-fault ground motion is larger than that of the parallel component, which agrees with the conclusions of the acceleration, displacement, and interstory drift. In addition, the peak interstory shear forces of the structure have been reduced effectively by the viscous dampers.

In conclusion, the seismic responses of the structure in the SSI system with viscous dampers under the excitation of the horizontal components of near-fault ground motions are larger than those of the parallel components, demonstrating the more obvious influence of the horizontal components in near-fault ground records on the seismic responses of the structure than that of the parallel component. In addition, the seismic responses of the structure are mitigated by the viscous dampers effectively.

\section{Conclusions}

In this present study, a ten-story reinforced concrete frame rested on soft site is introduced, and the viscous dampers added in the frame are designed. The numerical analysis methods of the soil-structure system with viscous dampers are established through ANSYS program. Then, near-fault ground motions with different characteristics are selected from Chi-Chi earthquakes, e.g., the hanging wall and footwall effect, the pulse-like ground motions like forwarddirectivity velocity pulse, fling-step velocity pulse, and nonspeed velocity pulse, and horizontal component and parallel component in forward-directivity ground motions. Furthermore, the response spectra of these selected nearfault ground motions are investigated, and a nonlinear dynamic time-history analysis is performed on the SSI system with viscous dampers subjected to the selected nearfault ground shakings. The following are several conclusions drawn from this work, which may help understand the seismic performance of buildings rested on near-fault regions comprehensively.

(1) The presence of viscous dampers, a passive energy dissipation device, reveals good efficiency on mitigating the seismic responses of the structure rested on soft site in the SSI system subjected to the excitations of near-fault ground motions.

(2) The seismic responses of the structure are obviously larger under the near-fault ground motions with hanging wall effect than the footwall effect, indicating the distinct hanging wall effect. However, the hanging wall effect is not obvious with the modulation of PGA.

(3) The performance of the structure is more influenced by the fling-step effect than the forward-directivity effect, which is related to the dynamic characteristics of the structure, frequency components, and the response spectra characteristics of the ground motions.

(4) The structural responses subjected to the horizontal components of near-fault ground records are larger than those of the parallel components, demonstrating the distinct influence of the horizontal component on the seismic responses of the structure. 
The analytical results verify that the structure with viscous dampers in the SSI system is more sensitive to the hanging wall effect, fling-step effect, and horizontal component than the footwall effect, forward-directivity effect, and parallel component in near-fault ground motions, respectively. In other words, these distinct effects of near-fault ground motions are unfavorable to the structure. Consequently, it is of great importance to consider the hanging wall effect, pulse-like motions, the horizontal component of forward-directivity effect ground motions in the performance-based seismic design of viscous dampers, and structures rested in the near-fault ground regions.

\section{Data Availability}

In this present study, a ten-story reinforced concrete frame rested on soft site is introduced and the viscous dampers added in the frame are designed. The numerical analysis methods of the soil-structure system with viscous dampers are established through ANSYS program. The results are based on the finite element software. The data of the paper are available from the corresponding author upon request via e-mail.

\section{Conflicts of Interest}

The authors declare that they have no conflicts of interest.

\section{Acknowledgments}

This study was funded by the National Key R\&D Program of China (grant no. 2018YFC0705602), the National Natural Science Foundations of China (grant nos. 51978524 and 51608176), the Open Project of Henan Key Laboratory of Grain Storage Facility and Safety (grant no. 2016KF-B01), and the Science and Technology Research Project of Henan Province Office of Education (grant no. 20A560009).

\section{References}

[1] K. Galal and M. Naimi, "Effect of soil conditions on the response of reinforced concrete tall structures to near-fault earthquakes," The Structural Design of Tall and Special Buildings, vol. 17, no. 3, pp. 541-562, 2008.

[2] S. Shahbazi, I. Mansouri, J. W. Hu, N. Sam Daliri, and A. Karami, "Seismic response of steel SMFs subjected to vertical components of far- and near-field earthquakes with forward directivity effects," Advances in Civil Engineering, vol. 2019, Article ID 2647387, 15 pages, 2019.

[3] Z. Chang, F. Luca, and K. Goda, "Automated classification of near-fault acceleration pulses using wavelet packets," Computer-Aided Civil and Infrastructure Engineering, vol. 34, no. 7, pp. 569-585, 2019.

[4] J. W. Baker, "Quantitative classification of near-fault ground motions using wavelet analysis," Bulletin of the Seismological Society of America, vol. 97, no. 5, pp. 1486-1501, 2007.

[5] S. K. Shahi and J. W. Baker, "An empirically calibrated framework for including the effects of near-fault directivity in probabilistic seismic hazard analysis," Bulletin of the Seismological Society of America, vol. 101, no. 2, pp. 742-755, 2011.
[6] T. Zhou and A.-Q. Li, "Stochastic modeling and synthesis of near-fault forward-directivity ground motions," KSCE Journal of Civil Engineering, vol. 24, no. 2, p. 483, 2020.

[7] G. Quaranta and F. Mollaioli, "Analysis of near-fault pulse-like seismic signals through variational Mode Decomposition Technique," Engineering Structures, vol. 193, pp. 121-135, 2019.

[8] J. Ruiz-García and J. C. Negrete-Manriquez, "Evaluation of drift demands in existing steel frames under as-recorded farfield and near-fault mainshock-aftershock seismic sequences," Engineering Structures, vol. 33, no. 2, pp. 621-634, 2011.

[9] W. Xu, Z. Luo, W. Yan, Y. Chen, and J. Wang, "Impact of pulse parameters on the seismic response of long-period bridges," Structure and Infrastructure Engineering, vol. 16, no. 10, p. 1461, 2020.

[10] J.-G. Xu, G. Wu, and D.-C. Feng, "Near fault ground motion effects on seismic resilience of frame structures damaged in Wenchuan earthquake," Structure and Infrastructure Engineering, vol. 16, no. 10, p. 1347, 2019.

[11] Z. Chang, F. De Luca, and K. Goda, "Near-fault acceleration pulses and non-acceleration pulses: effects on the inelastic displacement ratio," Earthquake Engineering \& Structural Dynamics, vol. 48, no. 11, pp. 1256-1276, 2019.

[12] N. Gunes and Z. C. Ulucan, "Nonlinear dynamic response of a tall building to near-fault pulse-like ground motions," Bulletin of Earthquake Engineering, vol. 17, no. 6, pp. 2989-3013, 2019.

[13] S. Li, F. Zhang, J. Q. Wang, M. S. Alam, and J. Zhang, "Effects of near-fault motions and artificial pulse-type ground motions on super-span cable-stayed bridge systems," Journal of Bridge Engineering, vol. 22, no. 3, 2017.

[14] J. Yang, P. Li, and Z. Lu, "Large-scale shaking table test on pile-soil-structure interaction on soft soils," The Structural Design of Tall and Special Buildings, vol. 28, no. 18, 2019.

[15] S. Kwag, B. Ju, and W. Jung, "Beneficial and detrimental effects of soil-structure interaction on probabilistic seismic hazard and risk of nuclear power plant," Advances in Civil Engineering, vol. 2018, Article ID 2698319, 18 pages, 2018.

[16] F. Khoshnoudian, E. Ahmadi, and S. Sohrabi, "Response of nonlinear soil-MDOF structure systems subjected to distinct frequency-content components of near-fault ground motions," Earthquake Engineering \& Structural Dynamics, vol. 43, no. 5, pp. 701-716, 2014.

[17] S. Li, F. Zhang, J.-q. Wang, M. S. Alam, and J. Zhang, "Seismic responses of super-span cable-stayed bridges induced by ground motions in different sites relative to fault rupture considering soil-structure interaction," Soil Dynamics and Earthquake Engineering, vol. 101, pp. 295-310, 2017.

[18] Y. Xiang, Y.-f. Luo, Q.-l. Huang, and Z.-y. Shen, "Vertical ductility demand and residual displacement of roof-type steel structures subjected to vertical earthquake ground motions," Soil Dynamics and Earthquake Engineering, vol. 104, pp. 259-275, 2018.

[19] D. Zou, H. Han, J. Liu, D. Yang, and X. Kong, "Seismic failure analysis for a high concrete face rockfill dam subjected to near-fault pulse-like ground motions," Soil Dynamics and Earthquake Engineering, vol. 98, pp. 235-243, 2017.

[20] H. Masaeli, F. Khoshnoudian, and R. Ziaei, "Rocking soilstructure systems subjected to near-fault pulses," Journal of Earthquake Engineering, vol. 19, no. 3, pp. 461-479, 2015.

[21] H. Güllü and M. Karabekmez, "Effect of near-fault and farfault earthquakes on a historical masonry mosque through 3D dynamic soil-structure interaction," Engineering Structures, vol. 152, pp. 465-492, 2017.

[22] G. R. Atefatdoost, B. JavidSharifi, and H. Shakib, "Effects of foundation flexibility on seismic demands of asymmetric 
buildings subject to near-fault ground motions," Structural Engineering and Mechanics, vol. 66, no. 5, pp. 637-648, 2018.

[23] Y. Tang and J. Zhang, "Probabilistic seismic demand analysis of a slender RC shear wall considering soil-structure interaction effects," Engineering Structures, vol. 33, no. 1, pp. 218-229, 2011.

[24] J. Zhang and Y. Tang, "Dimensional analysis of structures with translating and rocking foundations under near-fault ground motions," Soil Dynamics and Earthquake Engineering, vol. 29, no. 10, pp. 1330-1346, 2009.

[25] M. Apostolou, G. Gazetas, and E. Garini, "Seismic response of slender rigid structures with foundation uplifting," Soil Dynamics and Earthquake Engineering, vol. 27, no. 7, pp. 642654, 2007.

[26] F. Khoshnoudian, E. Ahmadi, and A. I. Azad, "Damping coefficients for soil-structure systems and evaluation of FEMA 440 subjected to pulse-like near-fault earthquakes," Soil Dynamics and Earthquake Engineering, vol. 61-62, pp. 124-134, 2014.

[27] F. Khoshnoudian, E. Ahmadi, S. Sohrabi, and M. Kiani, "Higher-mode effects for soil-structure systems under different components of near-fault ground motions," Earthquakes and Structures, vol. 7, no. 1, pp. 83-99, 2014.

[28] Y. Lu, I. Hajirasouliha, and A. M. Marshall, "Direct displacement-based seismic design of flexible-base structures subjected to pulse-like ground motions," Engineering Structures, vol. 168, pp. 276-289, 2018.

[29] A. Krishnamoorthy, "Effect of soil-structure interaction for a building isolated with FPS," Earthquakes and Structures, vol. 4, no. 3, pp. 285-297, 2013.

[30] Y. Cao, K. C. Meza-Fajardo, G. P. Mavroeidis, and A. S. Papageorgiou, "Effects of wave passage on torsional response of symmetric buildings subjected to near-fault pulselike ground motions," Soil Dynamics and Earthquake Engineering, vol. 88, pp. 109-123, 2016.

[31] E. Ahmadi and F. Khoshnoudian, "Near-fault effects on strength reduction factors of soil-MDOF structure systems," Soils and Foundations, vol. 55, no. 4, pp. 841-856, 2015.

[32] G. Minasidis, G. D. Hatzigeorgiou, and D. E. Beskos, "SSI in steel frames subjected to near-fault earthquakes," Soil Dynamics and Earthquake Engineering, vol. 66, pp. 56-68, 2014.

[33] N. Chouw and H. Hao, "Significance of SSI and nonuniform near-fault ground motions in bridge response I: effect on response with conventional expansion joint," Engineering Structures, vol. 30, no. 1, pp. 141-153, 2008.

[34] F. Mazza, "Seismic vulnerability and retrofitting by damped braces of fire-damaged r.c. framed buildings," Engineering Structures, vol. 101, no. 5, pp. 179-192, 2015.

[35] F. Mazza, "Effects of the long-term behaviour of isolation devices on the seismic response of base-isolated buildings," Structural Control and Health Monitoring, vol. 26, no. 4, Article ID e2331, 2019.

[36] D. P. N. Kontoni and A. A. Farghaly, "The effect of base isolation and tuned mass dampers on the seismic response of RC high-rise buildings considering soil-structure interaction," Earthquakes and Structures, vol. 17, no. 4, pp. 425-434, 2019.

[37] D. P. N. Kontoni and A. A. Farghaly, "TMD effectiveness for steel high-rise building subjected to wind or earthquake including soil-structure interaction," Wind and Structures, vol. 30, no. 4, pp. 423-432, 2020.

[38] J. Yang, Z. Lu, and P. Li, "Large-scale shaking table test on tall buildings with viscous dampers considering pile-soil-structure interaction," Engineering Structures, vol. 220, Article ID 110960, 2020.

[39] M. N. Domizio, D. Ambrosini, and O. Curadelli, "TMD effectiveness in nonlinear RC structures subjected to near fault earthquakes," Smart Structures and Systems, vol. 24, no. 4, pp. 447-457, 2019.

[40] W. Guo, X. L. Wu, X. N. Wei, Y. Cui, and D. Bu, "Inductance effect of passive electromagnetic dampers on building-damper system subjected to near-fault earthquakes," Advances in Structural Engineering, vol. 23, no. 2, pp. 20-333, 2020.

[41] G. Hu, Y. Wang, W. Huang, B. Li, and B. Luo, "Seismic mitigation performance of structures with viscous dampers under near-fault pulse-type earthquakes," Engineering Structures, vol. 203, Article ID 109878, 2020.

[42] W. Xie and L. M. Sun, "Experimental and numerical investigations on transverse seismic responses of soil-cable-stayedbridge system subjected to transverse near-fault ground motions," Engineering Structures, vol. 226, Article ID 111361, 2021.

[43] J. Yang, P. Li, Y. Yang, and D. Xu, “An improved EMD method for modal identification and a combined static-dynamic method for damage detection," Journal of Sound and Vibration, vol. 420, pp. 242-260, 2018.

[44] J. P. Yang, H. Jing, and P. Z. Li, "Dynamic characteristics and viscous dampers design for pile-soil-structure system," The Structural Design of Tall and Special Buildings, vol. 29, no. 14, Article ID e1785, 2020.

[45] D. De Domenico, G. Ricciardi, and I. Takewaki, "Design strategies of viscous dampers for seismic protection of building structures: a review," Soil Dynamics and Earthquake Engineering, vol. 118, pp. 144-165, 2019.

[46] F. Mazza, "Dissipative steel exoskeletons for the seismic control of reinforced concrete framed buildings," Structural Control and Health Monitoring, Article ID e2683, 2021.

[47] P. Li, J. Yang, and Z. Lu, "Shaking table test and theoretical analysis of the pile-soil-structure interaction at a liquefiable site," The Structural Design of Tall and Special Buildings, vol. 27, no. 15, p. e1513, 2018.

[48] J. Yang, P. Li, and Z. Lu, "Numerical simulation and in-situ measurement of ground-borne vibration due to subway system," Sustainability, vol. 10, no. 7, p. 2439, 2018.

[49] Y. F. Yang, Y. L. Liu, and L. Ling, "Study on seismic resistance behavior of the mountain isolated frame structure connected with ground by not only the first floor," China Civil Engineering Journal, vol. 47, no. S1, pp. 11-16, 2014.

[50] S. Li, J. Liu, Z. Yang et al., "Multiscale method for seismic response of near-source sites," Advances in Civil Engineering, vol. 2020, Article ID 8183272, 19 pages, 2020. 